\title{
Influences of emission sources and meteorology on aerosol chemistry in a polluted urban environment: results from DISCOVER-AQ California
}

\author{
Dominique E. Young $^{1}$, Hwajin Kim ${ }^{1, a}$, Caroline Parworth ${ }^{1}$, Shan Zhou ${ }^{1}$, Xiaolu Zhang ${ }^{2}$, Christopher D. Cappa ${ }^{2}$, \\ Roger Seco ${ }^{3}$, Saewung Kim ${ }^{3}$, and Qi Zhang ${ }^{1}$ \\ ${ }^{1}$ Department of Environmental Toxicology, University of California, Davis, CA 95616, USA \\ ${ }^{2}$ Department of Civil and Environmental Engineering, University of California, Davis, CA 95616, USA \\ ${ }^{3}$ Department of Earth System Science, University of California, Irvine, CA 92697, USA \\ anow at: Center for Environment, Health and Welfare Research, Korea Institute Science and Technology, \\ Seoul, Korea \\ Correspondence to: Qi Zhang (dkwzhang@ucdavis.edu)
}

Received: 7 November 2015 - Published in Atmos. Chem. Phys. Discuss.: 15 December 2015

Revised: 6 April 2016 - Accepted: 11 April 2016 - Published: 2 May 2016

\begin{abstract}
The San Joaquin Valley (SJV) in California experiences persistent air-quality problems associated with elevated particulate matter (PM) concentrations due to anthropogenic emissions, topography, and meteorological conditions. Thus it is important to unravel the various sources and processes that affect the physicochemical properties of PM in order to better inform pollution abatement strategies and improve parameterizations in air-quality models.

During January and February 2013, a ground supersite was installed at the Fresno-Garland California Air Resources Board (CARB) monitoring station, where comprehensive, real-time measurements of PM and trace gases were performed using instruments including an Aerodyne highresolution time-of-flight aerosol mass spectrometer (HRToF-AMS) and an Ionicon proton transfer reaction timeof-flight mass spectrometer (PTR-TOF-MS) as part of the NASA Deriving Information on Surface Conditions from Column and Vertically Resolved Observations Relevant to Air Quality (DISCOVER-AQ) campaign. The average submicron aerosol $\left(\mathrm{PM}_{1}\right)$ concentration was $31.0 \mu \mathrm{g} \mathrm{m}^{-3}$ and the total mass was dominated by organic aerosols (OA, $55 \%)$, followed by ammonium nitrate (35\%). High PM pollution events were commonly associated with elevated OA concentrations, mostly from primary sources. Organic aerosols had average atomic oxygen-to-carbon $(\mathrm{O} / \mathrm{C})$, hydrogen-tocarbon $(\mathrm{H} / \mathrm{C})$, and nitrogen-to-carbon $(\mathrm{N} / \mathrm{C})$ ratios of 0.42 , 1.70 , and 0.017 , respectively. Six distinct sources of or-
\end{abstract}

ganic aerosol were identified from positive matrix factorization (PMF) analysis of the AMS data: hydrocarbon-like OA (HOA; $9 \%$ of total OA, O $/ \mathrm{C}=0.09$ ) associated with local traffic, cooking OA (COA; $18 \%$ of total OA, O $/ \mathrm{C}=0.19$ ) associated with food cooking activities, two biomass burning OA (BBOA1: $13 \%$ of total OA, $\mathrm{O} / \mathrm{C}=0.33$; BBOA2: $20 \%$ of total $\mathrm{OA}, \mathrm{O} / \mathrm{C}=0.60)$ most likely associated with residential space heating from wood combustion, and semivolatile oxygenated OA (SV-OOA; $16 \%$ of total OA, $\mathrm{O} / \mathrm{C}=0.63)$ and low-volatility oxygenated OA (LV-OOA; $24 \%$ of total $\mathrm{OA}, \mathrm{O} / \mathrm{C}=0.90$ ) formed via chemical reactions in the atmosphere.

Large differences in aerosol chemistry at Fresno were observed between the current campaign (winter 2013) and a previous campaign in winter 2010 , most notably that $\mathrm{PM}_{1}$ concentrations were nearly 3 times higher in 2013 than in 2010. These variations were attributed to differences in the meteorological conditions, which influenced primary emissions and secondary aerosol formation. In particular, COA and BBOA concentrations were greater in 2013 than 2010, where colder temperatures in 2013 likely resulted in increased biomass burning activities. The influence from a nighttime formed residual layer that mixed down in the morning was found to be much more intense in 2013 than 2010 , leading to sharp increases in ground-level concentrations of secondary aerosol species including nitrate, sulfate, and OOA, in the morning between 08:00 and 12:00 PST. This 
is an indication that nighttime chemical reactions may have played a more important role in 2013. As solar radiation was stronger in 2013 the higher nitrate and OOA concentrations in 2013 could also be partly due to greater photochemical production of secondary aerosol species. The greater solar radiation and larger range in temperature in 2013 also likely led to both SV-OOA and LV-OOA being observed in 2013 whereas only a single OOA factor was identified in 2010.

\section{Introduction}

Ambient aerosols have long been recognized as having adverse effects on human health (Pope and Dockery, 2006) although it is unclear which aerosol property, or properties, are responsible for such effects (Harrison and Yin, 2000). Atmospheric particles can also significantly impact the Earth's climate (Pöschl, 2005) and represent one of largest sources of uncertainty in predicting future climate change (IPCC, 2013), primarily due to the complex nature of the particles. This is in part due to many different components contributing to particulate matter (PM), which have a range of chemical compositions and originate from a large range of sources and processes (Seinfeld and Pandis, 2006). This is especially true in the case of organic aerosols (OA), which often represent the largest component of the total fine PM mass, contributing up to $90 \%$ depending on location (Kanakidou et al., 2005; Zhang et al., 2007a). However, the sources, atmospheric aging, properties, and impacts of OA are not well understood despite being the focus of numerous studies (e.g., Gelencsér et al., 2007; Jimenez et al., 2009; Ng et al., 2010; Ervens et al., 2011).

In addition to effects on human health and climate, aerosols are also known to influence air quality, and elevated PM concentrations are common issues in urban areas due to anthropogenic emissions and meteorological conditions (Watson, 2002). The importance of different emissions and conditions varies with season; increased primary emissions coupled with stagnant conditions in winter result in pollution events, whereas increased photochemical activity during the summer leads to photochemical haze or smog (Goldstein et al., 2009; Martin et al., 2011). The San Joaquin Valley (SJV) in California experiences persistent air-quality problems and remains one of the most polluted regions in the USA despite many years of regulatory control efforts (e.g., Chow et al., 2006). Located in central California with mountainous topography, the geographic features of the SJV trap pollutants and subsequently lead to deterioration of air quality, particularly during winter. Consequently, the SJV often exceeds the National Ambient Air Quality Standards (NAAQS) for $\mathrm{PM}_{2.5}$ and $\mathrm{PM}_{10}$ (particles with aerodynamic diameters less than 2.5 and $10 \mu \mathrm{m}$, respectively) (Gorin et al., 2006; Lurmann et al., 2006; Ngo et al., 2010). In addition, residents of the SJV suffer the highest rates of cardiorespiratory diseases in the country (Hall et al., 2008; American Lung Association, 2016).

Previous studies have shown that the composition of ambient aerosols in Fresno, one of the most populated cities in the SJV, is complex, with organic species representing an important component of PM, often contributing up to two-thirds of the total mass (Chu et al., 2004; Chow et al., 2006; Turkiewicz et al., 2006; Ge et al., 2012a). Intense urban and agricultural emissions have been found to contribute to both local and regional PM pollution problems in Fresno (Chow et al., 1993; Watson et al., 2000; Sorooshian et al., 2008; Ge et al., 2012a). PM pollution is particularly severe in winter due to a combination of factors including elevated emissions from residential wood combustion for heating and lower boundary layer (BL) height and stagnant conditions that favor the accumulation of PM and secondary aerosol precursors (Brown et al., 2006a). In addition, the typical cold and high-humidity weather in the winter promotes gasto-particle partitioning of semivolatile species. Regional fog events that enhance aqueous-phase formation of sulfate and secondary organic aerosol (SOA) also frequently occur in the area (Collett et al., 1999; Herckes et al., 2007; Ge et al., 2012a, b). The interactions between these factors affect the composition, size, hygroscopicity, and optical properties of wintertime aerosols within the SJV in a complicated and dynamic manner (Ge et al., 2012a, b). Unraveling the various sources and processes affecting the physicochemical properties of aerosols as well as how these change both temporally and spatially is important to better inform and further develop pollution abatement strategies and to improve parameterizations in air-quality models. In particular, detailed information obtained from in situ measurements can facilitate fundamental understanding of processes that influence formation, properties, and transport of atmospheric aerosols and can lead to improvements in our ability to predict how changes in atmospheric composition influence air quality.

As part of the NASA DISCOVER-AQ (Deriving Information on Surface conditions from COlumn and VERtically resolved observations relevant to Air Quality) campaign many aerosol, gas-phase, and meteorological measurements were made during winter 2013 at the ground supersite in Fresno at the Fresno-Garland California Air Resources Board (CARB) monitoring station. The aim of this study was to obtain a comprehensive and detailed understanding of the chemical, microphysical, and optical properties of wintertime aerosols within the SJV and the processes that drive the observed temporal and diurnal variations and vertical distribution of particles over this region. Here we report the results from an Aerodyne high-resolution time-of-flight aerosol mass spectrometer (HR-ToF-AMS) which was deployed for the 4-week intensive measurement campaign to characterize size-resolved chemical composition of non-refractory submicron particulates $\left(\mathrm{NR}-\mathrm{PM}_{1}\right)$ with high time resolution (Canagaratna et al., 2007). In addition to the high-resolution mass spectra (HRMS) and elemental ratios determined by the HR-ToF- 
AMS (Aiken et al., 2008; Canagaratna et al., 2015), factor analysis of aerosol mass spectra can provide insight into the sources, evolution, and temporal trends of OA (Zhang et al., 2011). In this paper we will discuss the chemical composition of the aerosols at Fresno, particularly the results from analysis of the OA fraction using positive matrix factorization (PMF) (Ulbrich et al., 2009) including the detailed chemical composition of the resolved components and their temporal variations to investigate emission sources. Volatile organic compound (VOC) measurements from the proton transfer reaction time-of-flight mass spectrometer (PTR-TOF-MS) are used to help interpret AMS data and to support the aerosol sources identified from factor analysis. In addition we will also compare results with those obtained from a similar study performed in 2010 to gain insight into the role of meteorology in influencing aerosol chemical composition.

\section{Experimental methods}

\subsection{DISCOVER-AQ project}

DISCOVER-AQ is a coordinated effort mission combining surface and aircraft-based measurements to characterize and understand how aerosols and trace gases evolve throughout the day and across urban areas. The overarching aim of the DISCOVER-AQ project (http://discover-aq.larc.nasa.gov/) is to relate concurrent observations of column abundances to surface concentrations of key gaseous pollutants and aerosols to improve the interpretation of satellite observations and diagnoses of near-surface air quality (http://discover-aq.larc. nasa.gov/pdf/DISCOVER-AQ_science.pdf). One of the objectives is to characterize the differences in diurnal variation of surface and column observations for key trace gases and aerosols. To achieve this goal, gas- and particle-phase measurements were made throughout the day from two aircraft and a network of US ground sites that experience diverse meteorological and surface conditions. The factors that contribute to local air-quality problems (e.g., emissions, transport, and chemistry) also vary between the sites. Of the two aircraft, the NASA P-3B made daytime measurements close to the ground, at constant altitudes of $\sim 2500$ or $\sim 400 \mathrm{~m}$, or flew in tight spirals to measure vertical profiles throughout the SJV (Fig. 1a). The vertical profile measurements were made over seven select ground locations, including the Fresno supersite where detailed ground measurements were made to allow for quantitative connections to be made between the surface aerosol concentrations and properties and those observed aloft (e.g., Pusede et al., 2016). Data from the DISCOVER-AQ project are available to the public at http://www-air.larc.nasa.gov/missions/discover-aq/ discover-aq.html.

\subsection{Fresno supersite and instrumentation}

Situated approximately $320 \mathrm{~km}$ north of Los Angeles, $260 \mathrm{~km}$ east of the Pacific Ocean, and $275 \mathrm{~km}$ south of Sacramento, Fresno is an ideal location to study the influence of different sources on PM. Therefore, there was a particular focus on aerosol properties and processes in the winter 2013 DISCOVER-AQ campaign which took place from 13 January to 10 February. During this time, the weather was cold (average temperature of $7.9^{\circ} \mathrm{C}$ ) and relatively dry (average relative humidity (RH) of $69 \%$ ) with frequent sunshine. Comprehensive, real-time measurements of particle composition, size distribution, optical and radiative properties, hygroscopicity, and volatility along with a broad suite of in situ gas-phase and aerosol column measurements were made at the ground supersite at the Fresno-Garland monitoring station of CARB $\left(36.7854^{\circ},-119.7732^{\circ} ; 97 \mathrm{~m}\right.$ a.s.l.; Fig. 1a). A wide range of meteorological and air-quality data were also collected routinely by CARB from this site. The Yosemite FWY-41 highway is located approximately $1 \mathrm{~km}$ to the west of the sampling site; residential areas surround the site to the north and a commercial area is to the south (Fig. 1b).

Highly time-resolved in situ PM measurements at the Fresno supersite provide the data necessary to elucidate aerosol sources and processes and to interpret the comprehensive airborne data sets and remote sensing observations. The setup of the real-time particle instruments deployed at the Fresno supersite is shown in Fig. 1c. NR-PM 1 chemical composition and speciated size distributions were measured by an Aerodyne HR-ToF-AMS at a time resolution of 2.5 min and measurements of $\mathrm{PM}_{2.5}$ water-soluble composition of both inorganic and organic ions, including sulfate, nitrate, nitrite, ammonium, sodium, potassium, formate, and glycolate, were obtained using the particle-into-liquid sampler (PILS; Metrohm) coupled with two ion chromatography (IC) systems (Parworth et al., 2016). Black carbon (BC) mass concentration and size distribution (between $\sim 100$ and $400 \mathrm{~nm}$ volume equivalent diameter) were measured with the single particle soot photometer (SP2; DMT) (Schwarz et al., 2006), which measures the per-particle mass of refractory $\mathrm{BC}$ in individual particles by illuminating particles with high-intensity $1064 \mathrm{~nm}$ radiation. Further information on the operation and analysis of the SP2 can be found in Zhang et al. (2016). For VOC analysis an Ionicon high-resolution PTR-TOF-MS 8000 (Ionicon Analytik, Austria) was used (Graus et al., 2010; Müller et al., 2013). Particle size distributions were measured with a scanning mobility particle sizer (SMPS) over the mobility diameter range 8-858 nm (Setyan et al., 2012). The hourly ambient temperature and RH data as well as trace-gas (e.g., $\mathrm{CO}$ and $\mathrm{NO}_{2}$ ) concentrations were acquired from the CARB website (http://www.arb.ca.gov/html/ ds.htm). Solar radiation measurements were obtained from the nearby Clovis site $\left(36.8193^{\circ},-119.7164^{\circ} ; 113 \mathrm{~m}\right.$ a.s.l.) maintained by the San Joaquin Air Pollution Control District. 

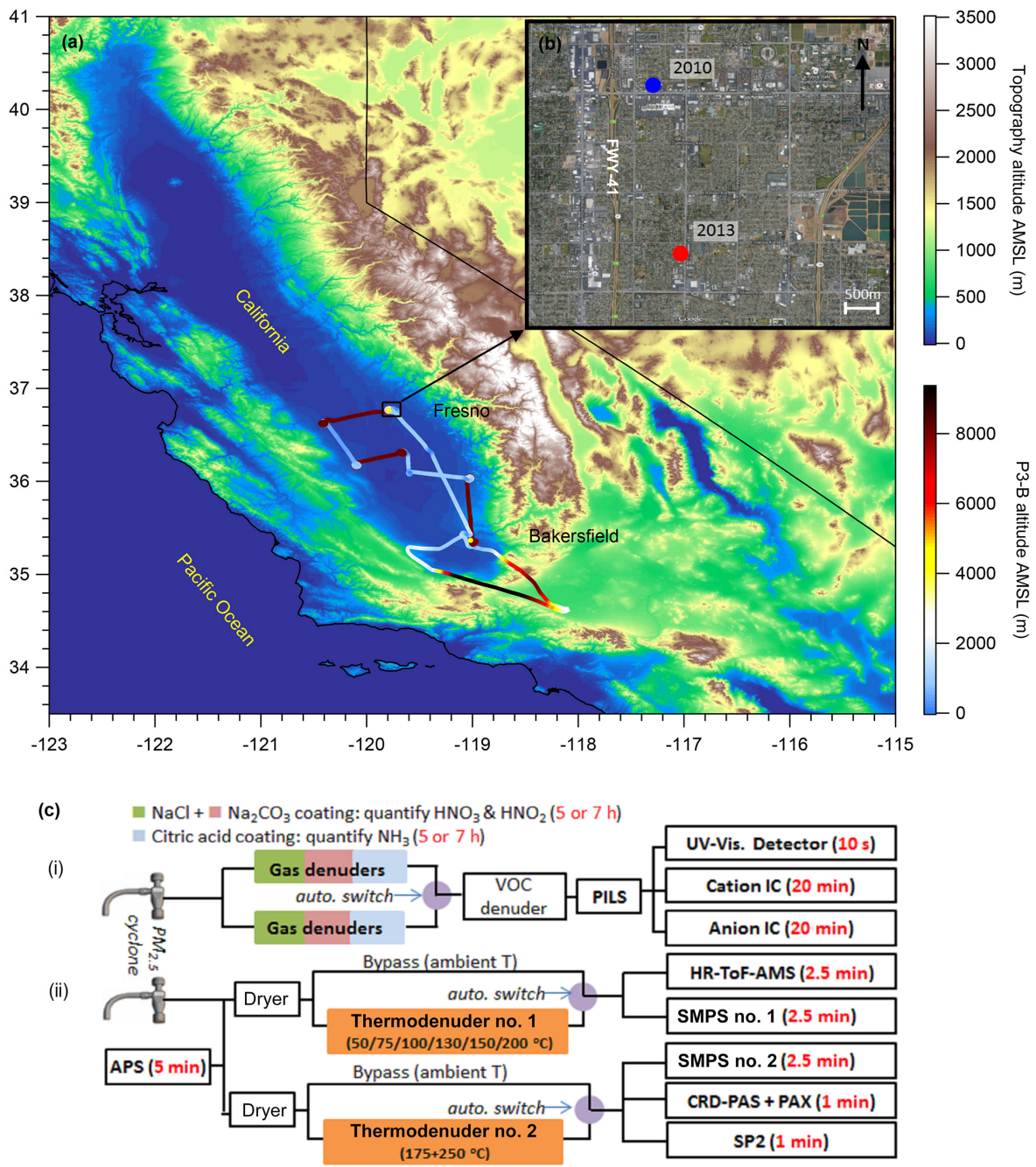

Figure 1. (a) Topographical map of the San Joaquin Valley (SJV) of California and NASA P-3B flight tracks during the winter 2013 DISCOVER-AQ campaign; (b) the inset shows the location of the supersite in Fresno from winter 2013 (denoted by the red circle) and the location of a similar campaign that took place in winter 2010 (Ge et al., 2012a, b) (denoted by the blue circle); (c) setup of the real-time instruments deployed at the Fresno supersite. (i) A particle-into-liquid sampler (PILS) was coupled with two ion chromatographs (IC) and a UV-vis detector. The PILS sampled after a fresh set of three annular denuders every 5 or $7 \mathrm{~h}$; (ii) After a PM 2.5 inlet, the flow was split into three paths: the first path included the high-resolution time-of-flight aerosol mass spectrometer (HR-ToF-AMS) and a scanning mobility particle sizer (SMPS) which sampled alternatively through a bypass line and a thermodenuder (TD). The second path included a SMPS, a cavity ring-down photoacoustic spectrometer (CRD-PAS) and particle extinctometer (PEX), and a single particle soot photometer (SP2). A TD was used to volatilize aerosol at $175^{\circ} \mathrm{C}$ then $250^{\circ} \mathrm{C}$. The third path led to an aerodynamic particle sizer (APS).

The solar radiation sensor is a Met One instrument, model 095, with a broadband spectral response between 285 and $2800 \mathrm{~nm}$. The data reported in this paper are in local time, which is Pacific standard time (PST) and $8 \mathrm{~h}$ earlier than coordinated universal time (UTC).

The focus of this study is on the measurements from the HR-ToF-AMS (DeCarlo et al., 2006), which was operated in the standard configuration and sampled mass spectra and particle time-of-flight data downstream of a $\mathrm{PM}_{2.5}$ cyclone (URG) (Fig. 1c). Further, the HR-ToF-AMS was operated under "V" and "W" ion optical modes, where higher sen- sitivity but lower mass resolution is achieved in "V" mode, and lower sensitivity but higher mass resolution is achieved with "W" mode. Ionization efficiency and particle sizing calibrations were performed following standard protocols (Canagaratna et al., 2007) on 13, 19, and 8 February. 


\subsection{Data analysis}

\subsubsection{Basic HR-ToF-AMS data analysis and intercomparisons with collocated measurements}

HR-ToF-AMS data were processed and analyzed within Igor Pro (Wavemetrics) using the standard ToF-AMS analysis toolkit software package, SQUIRREL (SeQUential Igor data RetRiEval) v1.56D, and the PIKA module v1.15D (available for download at http://cires.colorado.edu/jimenez-group/ ToFAMSResources/ToFSoftware/index.html). The standard fragmentation table described by Allan et al. (2004) was used with some small modifications to process the raw mass spectra. The modifications were based on data from three filtered air periods during the campaign, which enable the contribution of background gas-phase signal to be estimated and removed from the particle-phase signals. Adjustments made included those to the measured $\mathrm{CO}_{2}^{+}(m / z=44)$ signal in order to remove contributions from gas-phase $\mathrm{CO}_{2}$ as well as the ${ }^{15} \mathrm{~N}^{+}$to ${ }^{14} \mathrm{~N}^{+}$ratio for air signals at $m / z=29$. For improved oxygen-to-carbon $(\mathrm{O} / \mathrm{C})$ estimations, there is a need to perform a time-dependent $\mathrm{CO}_{2}^{+}$subtraction (Collier and Zhang, 2013); however, due to high organic aerosol loading during this study, gas-phase contribution represented a minor fraction of the total $\mathrm{CO}_{2}^{+}$signal and using a constant background $\mathrm{CO}_{2}^{+}$subtraction had little influence on the determination of org- $\mathrm{CO}_{2}^{+}$signals. Relative ionization efficiencies of 1.05, 1.256, and 3.65 were used for nitrate, sulfate, and ammonium, respectively, and were determined based on calibrations using pure $\mathrm{NH}_{4} \mathrm{NO}_{3}$ and $\left(\mathrm{NH}_{4}\right)_{2} \mathrm{SO}_{4}$ particles. Although applying a collection efficiency (CE) of 0.5 (default) to whole data sets has been deemed valid for measurements from most ambient environments, several factors, including the relative humidity of the sampling line, ammonium nitrate content, and acidity/neutralization of the sulfate content, have been found to influence the particle phase in the AMS. Consequently, a time- and composition-dependent CE was applied to the data based on the algorithm by Middlebrook et al. (2012). Although nitrate was often observed to be an important component of $\mathrm{PM}_{1}$ during this study, the campaign average $( \pm 1 \sigma) \mathrm{CE}$ was $0.5 \pm 0.04$. Quantification of NR-PM $\mathrm{PM}_{1}$ species was validated through comparisons between the total $\mathrm{PM}_{1}$ mass concentration (NR-PM plus BC) and the apparent particle volume concentration from the SMPS (Fig. S1 in the Supplement). The AMS total mass-based size distribution compares well with the volume size distribution of the SMPS throughout the day (Fig. S2). Extensive comparisons were also made between the AMS and PILS-IC measurements, where strong correlations were found for nitrate $\left(\mathrm{NO}_{3}^{-}\right)$, sulfate $\left(\mathrm{SO}_{4}^{2-}\right)$, ammonium $\left(\mathrm{NH}_{4}^{+}\right)$, and chloride $\left(\mathrm{Cl}^{-}\right)$(Pearson's $r$ of $0.96,0.94$, 0.97 , and 0.90 , respectively) with orthogonal distance regression fit slopes of 1.26, 1.27, 1.34, and 1.25, respectively (Parworth et al., 2016). The difference between PILS-IC and AMS measurements is likely because the PILS-IC measures
$\mathrm{PM}_{2.5}$ and the AMS measures NR-PM 1 . Elemental ratios between oxygen $(\mathrm{O})$, carbon $(\mathrm{C})$, hydrogen $(\mathrm{H})$, and nitrogen $(\mathrm{N})$ as well as the ratio of organic mass to organic carbon $(\mathrm{OM} / \mathrm{OC})$ of OA were determined from analysis of the W mode HRMS data following the method reported recently in Canagaratna et al. (2015). This method is an update to the Aiken-ambient method (Aiken et al., 2008) and is referred to as the improved-ambient method. The elemental ratios calculated using both the Aiken-ambient and improved-ambient methods are detailed in Table S1 in the Supplement. The elemental ratios calculated using the Aiken-ambient method are compared to those calculated using the improved-ambient method (Fig. S3) and show high correlation: the slope and $r^{2}$ for $\mathrm{O} / \mathrm{C}$ are 0.76 and 0.995 , for $\mathrm{H} / \mathrm{C}$ are 0.91 and 0.980 , and for $\mathrm{OM} / \mathrm{OC}$ are 0.92 and 0.988 . These comparisons are consistent with the average differences for the ratios between the two methods reported in Canagaratna et al. (2015), with increases of 27,11 , and $9 \%$ for $\mathrm{O} / \mathrm{C}, \mathrm{H} / \mathrm{C}$, and $\mathrm{OM} / \mathrm{OC}$ ratios, respectively. Unless otherwise indicated, the $\mathrm{O} / \mathrm{C}, \mathrm{H} / \mathrm{C}$, and $\mathrm{OM} / \mathrm{OC}$ ratios stated in this paper from other studies have been calculated using the updated elemental analysis method and are detailed in the Supplement of Canagaratna et al. (2015) (Tables S1 and S2). This updated method reproduces ratios that are within $28 \%$ for $\mathrm{O} / \mathrm{C}$ and $13 \%$ for $\mathrm{H} / \mathrm{C}$ of the known molecular values of individual oxidized standards. The precision of these measurements, however, is much higher, with good mass spectral precision between different AMS instruments. Further, AMS mass spectra of structurally stable compounds are highly comparable to those in the NIST database.

\subsubsection{Positive matrix factorization of HR-ToF-AMS organic spectra}

PMF analysis was performed using the PMF2 algorithm in robust mode (Paatero and Tapper, 1994) and conducted using the PMF Evaluation Toolkit (PET) v2.05 (Ulbrich et al., 2009) downloaded from http://cires1.colorado. edu/jimenez-group/wiki/index.php/PMF-AMS_Analysis_ Guide\#PMF_Evaluation_Tool_Software. The data and error matrices were prepared according to the protocol as described by Ulbrich et al. (2009) and outlined in Table 1 of Zhang et al. (2011). In brief, a minimum error value was added to the error matrix and ions were assessed and treated according to their signal-to-noise ratio (SNR); ions with a SNR less than 0.2 were removed and those with a SNR between 0.2 and 2 were down weighted by increasing their errors by a factor of 2 . Further, ions related to $m / z 44$ $\left(\mathrm{CO}_{2}^{+}\right)$were also down weighted so as to not overestimate the contribution of $\mathrm{CO}_{2}^{+}$. Finally, isotopes were not included in the matrices as their signals are scaled to their parent ions rather than being measured directly. The resulting matrix therefore consisted of ions between $\mathrm{m} / z \mathrm{~s} 12$ and 120 .

PMF was applied to the data and the number of factors $(p)$ in the solution was explored from 1 up to 9. However, 
as the number of factors in the real data set is unknown and the PMF algorithm is able to provide a number of mathematically sound solutions which could be deemed physically meaningful, several criteria are used to carefully evaluate and select the appropriate number of factors from the model. As this is one of the most critical aspects of PMF analysis, the recommendations outlined in Zhang et al. (2011), including investigation of the key diagnostic plots, mass spectral signatures, diurnal profiles, and correlations with external tracers, were followed to assess the quality and suitability of a solution set.

Within the PMF analysis toolkit, there are several diagnostics that can be used to aid the choosing of the best modeled number of factors including $Q$ and $f_{\text {Peak }} Q$ is the quality of fit parameter and the ratio of the expected $Q\left(Q / Q_{\exp }\right)$ indicates how well the model fit the data; as the number of factors in a solution increase, the degrees of freedom increase and $Q / Q_{\text {exp }}$ decreases close to 1 as more data are able to be fit. The $f_{\text {Peak }}$ parameter is used to demonstrate the variation of the solutions and can indicate the rotational stability of the solution sets. Negative $f_{\text {Peak }}$ values result in variations in the time series and positive values result in variations in the mass spectra of the solutions. However, the solution set is most likely to be physically meaningful when $f_{\text {Peak }}$ is 0 (Paatero et al., 2002). In this study, the rotational stability of each of the solution sets were explored through the $f_{\text {Peak }}$ parameter from -1 to 1 , with an increment of 0.1 . The sixfactor solution with $f_{\text {Peak }} 0\left(Q / Q_{\text {exp }}=2.85\right)$ was chosen for further analyses; the solution was deemed robust and representative as it satisfied the above criteria including good separation of the temporal and mass spectral variations of the six factors. A summary of the key diagnostics is presented in Fig. S4 and a comparison of the factor mass spectra with reference mass spectra, including those determined from a campaign in Fresno in winter 2010, are listed in Table S2. The six-factor solution was found to be very stable as the mass fraction of each of the factors remained relatively constant between $f_{\text {Peaks }}-0.4$ and +1 , inclusive (Fig. S4c). Figure S5 shows the mass spectra and time series of the five- and sevenfactor solutions. Factors 5 and 2 in the five-factor solution set could be identified as hydrocarbon-like OA (HOA) and cooking OA (COA), respectively, but are more oxidized than similar factors from previous studies, possibly due to mixing of factors with an oxygenated OA (OOA) factor, thus implying the factors could be further separated. In contrast, the temporal variations of several factors are similar in the seven-factor solution set, indicative of factor splitting. In addition, three potential OOA factors are identified in the seven-factor solution (factors 1, 2, and 4), but the mass spectrum of factor 2 appears to be a combination of the other two factors. Further, factor 4 is predominantly composed of $m / z 43$, which is unlikely to be physically real. Consequently, the six-factor solution, including two biomass burning OA (BBOA) and two OOA factors, was deemed the best solution to represent the organic aerosols in this study.

\subsubsection{Estimation of the OA factor size distributions}

Size distributions can provide some insight into the nature of the aerosol such as whether they are primary or secondary in nature and whether they have likely undergone aqueousphase processing. The size distributions of each of the OA factors from PMF analysis were therefore determined using a multivariate linear regression algorithm defined as

$\mathbf{m s}_{t, i}=\sum_{p=1}^{n} \mathbf{m s}_{p} \times c_{p, t, i}$

where $\mathbf{m s}_{t, i}$ is the measured mass spectrum of organics in unit mass resolution (UMR) for time period $t$ and size bin $i, \mathbf{m s}_{p}$ is the UMR mass spectrum of the factor $p$ from PMF analysis of the OA HRMS, and $c_{p, t, i}$ is the corresponding fitting parameter. This algorithm decomposes the mass spectra of OA corresponding to individual size bins into the linear combination of the unit mass resolution mass spectra of the $n$ number of factors determined from PMF analysis of the HRMS, assuming the spectral profile of each factor in different size bins is constant.

In this study, all mass spectra consist of $\mathrm{m} / \mathrm{zs} 12$ to $120 \mathrm{amu}$. The measured organic mass spectral matrix is size resolved for the whole measurement period over the size range $40-1200 \mathrm{~nm}$ and to improve the SNR the matrix was averaged into 23 size bins. This input data vector, $\mathbf{m s}_{t, i}$, was also normalized to the average OA mass spectrum from highresolution analysis prior to being linearly decomposed. For this analysis only four main OA factors were used (HOA, $\mathrm{COA}, \mathrm{BBOA}$, and OOA), as a more robust result was obtained compared to when all six individual factors were used. The mass spectra of the two BBOA factors were summed according to the contribution of each of the two factors to total BBOA mass and the time series were summed prior to linear decomposition. The semivolatile OOA (SV-OOA) and lowvolatility OOA (LV-OOA) factors were treated in the same way to produce a total average OOA mass spectrum and time series. A summary of the key diagnostics from the fitting is presented in Fig. S6, where it can be seen that for each size bin there is good agreement between the reconstructed OA and the measured OA ( $r=0.9993$, Fig. S6a). Furthermore, the mass-weighted size distributions of the four OA factors, which are normalized to their corresponding mass concentrations, compare well with that of the total organics (Fig. S6d).

\subsubsection{Calculation of the ammonium nitrate gas-to-particle partitioning equilibrium constant}

The oxidation of nitrogen dioxide $\left(\mathrm{NO}_{2}\right)$ in the atmosphere forms nitric acid $\left(\mathrm{HNO}_{3}\right)$, which tends to remain in the gas phase when there is limited availability of ammonia $\left(\mathrm{NH}_{3}\right)$. However, when sufficient $\mathrm{NH}_{3}$ is available (e.g., Lurmann et al., 2006), as is the case in the $\mathrm{SJV}, \mathrm{HNO}_{3}$ reacts with $\mathrm{NH}_{3}$ to form particulate $\mathrm{NH}_{4} \mathrm{NO}_{3}$ (Eq. 2). 
$\mathrm{NH}_{3}(\mathrm{~g})+\mathrm{HNO}_{3}(\mathrm{~g}) \leftrightarrow \mathrm{NH}_{4} \mathrm{NO}_{3}(\mathrm{~s})$

The partitioning between the gas and particle phases depends strongly on the ambient temperature and the equilibrium constant $K_{\mathrm{AN}}$ of Eq. (2) can be calculated as

$$
\begin{aligned}
K_{\mathrm{AN}} & =K_{\mathrm{AN}}(298) \\
& \exp \left\{\mathrm{a}\left(\frac{298}{T}-1\right)+\mathrm{b}\left[1+\ln \left(\frac{298}{T}\right)-\frac{298}{T}\right]\right\},
\end{aligned}
$$

where $T$ is the ambient temperature in Kelvin, $K_{\mathrm{AN}}(298)=3.36 \times 10^{16}\left(\mathrm{~atm}^{-2}\right), a=75.11$, and $b=-13.5$ (Seinfeld and Pandis, 2006).

\subsubsection{Derivation of the $\mathrm{HNO}_{3}$ production rate}

Overnight, $\mathrm{NO}_{2}$ and $\mathrm{O}_{3}$ react to form $\mathrm{N}_{2} \mathrm{O}_{5}$, which can react heterogeneously to form $\mathrm{HNO}_{3}$. The equations governing the nighttime formation of $\mathrm{N}_{2} \mathrm{O}_{5}$, nitrate radical $\left(\mathrm{NO}_{3}\right)$, and $\mathrm{HNO}_{3}$ are

$\mathrm{NO}_{2}+\mathrm{O}_{3} \rightarrow \mathrm{NO}_{3}+\mathrm{O}_{2}$,

$\mathrm{NO}_{3}+\mathrm{NO}_{2} \rightarrow \mathrm{N}_{2} \mathrm{O}_{5}$

$\mathrm{N}_{2} \mathrm{O}_{5} \rightarrow \mathrm{NO}_{2}+\mathrm{NO}_{3}$,

$\mathrm{N}_{2} \mathrm{O}_{5}+\mathrm{H}_{2} \mathrm{O}$ (het) $\rightarrow 2 \mathrm{HNO}_{3}$.

From Eqs. (4-6), the formation rates of $\mathrm{NO}_{3}, \mathrm{~N}_{2} \mathrm{O}_{5}$, and $\mathrm{HNO}_{3}$ can be derived as follows:

$$
\begin{aligned}
\frac{\mathrm{d}\left[\mathrm{NO}_{3}\right]}{\mathrm{d} t}= & -k_{5 a}\left[\mathrm{NO}_{2}\right]\left[\mathrm{NO}_{3}\right]+k_{5 b}\left[\mathrm{~N}_{2} \mathrm{O}_{5}\right] \\
& +k_{4}\left[\mathrm{NO}_{2}\right]\left[\mathrm{O}_{3}\right], \\
\frac{\mathrm{d}\left[\mathrm{N}_{2} \mathrm{O}_{5}\right]}{\mathrm{d} t} & =-k_{6}\left[\mathrm{~N}_{2} \mathrm{O}_{5}\right]-k_{5 b}\left[\mathrm{~N}_{2} \mathrm{O}_{5}\right] \\
& +k_{5 a}\left[\mathrm{NO}_{2}\right]\left[\mathrm{NO}_{3}\right], \\
\frac{\mathrm{d}\left[\mathrm{HNO}_{3}\right]}{\mathrm{d} t} & =k_{6}\left[\mathrm{~N}_{2} \mathrm{O}_{5}\right] .
\end{aligned}
$$

If one assumes that $\mathrm{N}_{2} \mathrm{O}_{5}$ and $\mathrm{NO}_{3}$ are both in steady state (Brown et al., 2006b), the net production rates for both species should be 0 ; thus their steady-state concentrations are

$\left[\mathrm{NO}_{3}\right]_{\mathrm{SS}}=\frac{k_{5 b}\left[\mathrm{~N}_{2} \mathrm{O}_{5}\right]+k_{4}\left[\mathrm{NO}_{2}\right]\left[\mathrm{O}_{3}\right]}{k_{5 a}\left[\mathrm{NO}_{2}\right]}$,

$\left[\mathrm{N}_{2} \mathrm{O}_{5}\right]_{\mathrm{SS}}=\frac{k_{5 a}\left[\mathrm{NO}_{2}\right]\left[\mathrm{NO}_{3}\right]}{k_{6}+k_{5 b}}$.
By combining Eqs. (9-11), we found that both the steadystate concentration of $\mathrm{N}_{2} \mathrm{O}_{5}$ and the nighttime production rate of $\mathrm{HNO}_{3}$ are proportional to the product of the concentrations of $\mathrm{NO}_{2}$ and $\mathrm{O}_{3}$ :

$$
\begin{aligned}
& {\left[\mathrm{N}_{2} \mathrm{O}_{5}\right]_{\mathrm{SS}}=\frac{k_{4}}{k_{6}}\left[\mathrm{NO}_{2}\right]\left[\mathrm{O}_{3}\right],} \\
& \frac{\mathrm{d}\left[\mathrm{HNO}_{3}\right]}{\mathrm{d} t}=k_{4}\left[\mathrm{NO}_{2}\right]\left[\mathrm{O}_{3}\right] .
\end{aligned}
$$

\section{Results and discussion}

\subsection{Temporal and diurnal variations of $\mathbf{P M}_{1}$ composition and size distribution}

Frequent PM pollution events were observed at Fresno during DISCOVER-AQ; $\mathrm{PM}_{1}$ concentrations exceeded the $24 \mathrm{~h}$ NAAQS for $\mathrm{PM}_{2.5}\left(35 \mu \mathrm{g} \mathrm{m}^{-3}\right)$ on $50 \%$ of the days (Fig. 2). $\mathrm{PM}_{2.5}$ concentrations are estimated to be approximately $25 \%$ greater than $\mathrm{PM}_{1}$ (Parworth et al., 2016); thus it is likely that $\mathrm{PM}_{2.5}$ concentrations violated these standards for two-thirds of the campaign. Between 13 January and 11 February 2013 the average $\mathrm{PM}_{1}$ concentration was $31.0 \mu \mathrm{g} \mathrm{m}^{-3}$, with a maximum concentration of $130 \mu \mathrm{g} \mathrm{m}^{-3}$ measured on 14 January (Fig. 2 and Table 1). OA contributed, on average, $55 \%$ to the total $\mathrm{PM}_{1}$ mass, representing the largest component, followed by $\mathrm{NO}_{3}^{-}(27 \%)$, with smaller contributions from $\mathrm{NH}_{4}^{+}$ (9\%), $\mathrm{BC}(5 \%), \mathrm{SO}_{4}^{2-}(3 \%)$, and $\mathrm{Cl}^{-}(1 \%)$ (Fig. 3a and Table 1). In addition, the molar equivalent ratios of total inorganic anions to ammonium $\left(=\left(\mathrm{SO}_{4}^{2-} / 48+\mathrm{NO}_{3}^{-} / 62+\right.\right.$ $\left.\left.\mathrm{Cl}^{-} / 35.5\right) /\left(\mathrm{NH}_{4}^{+} / 18\right)\right)$ were close to 1 , indicating the presence of neutralized inorganic aerosols in the form of ammonium salts during the campaign (Zhang et al., 2007b).

Diurnal patterns and particle size distributions can offer insight into aerosol sources, formation processes, and behavior. During this study, high OA and BC concentrations occurred overnight, with maximum concentrations usually observed at 22:00 PST (Fig. 4a and b), associated with a shallow BL coupled with enhanced emissions from activities such as biomass burning for residential space heating. In addition, a smaller morning peak ( 07:00-08:00 PST) is observed in the diurnal profiles of $\mathrm{BC}$ and can be associated with morning traffic rush hour. Conversely, daily variations in inorganic species concentrations were similar, with a sharp increase between 08:00 and 10:00 PST and peaking around midday (Fig. 4c-f), suggesting they have similar sources. This daytime peak in concentrations is consistent with previous observations (Brown et al., 2006a; Lurmann et al., 2006) and has been attributed to the mixing down of secondary aerosols formed at night in a residual layer aloft associated with BL dynamics (Watson and Chow, 2002a, b; Chow et al., 2006; Pusede et al., 2016). During this study, daytime BL heights were estimated to range between 300 and $700 \mathrm{~m}$ (Pusede et al., 2016). 

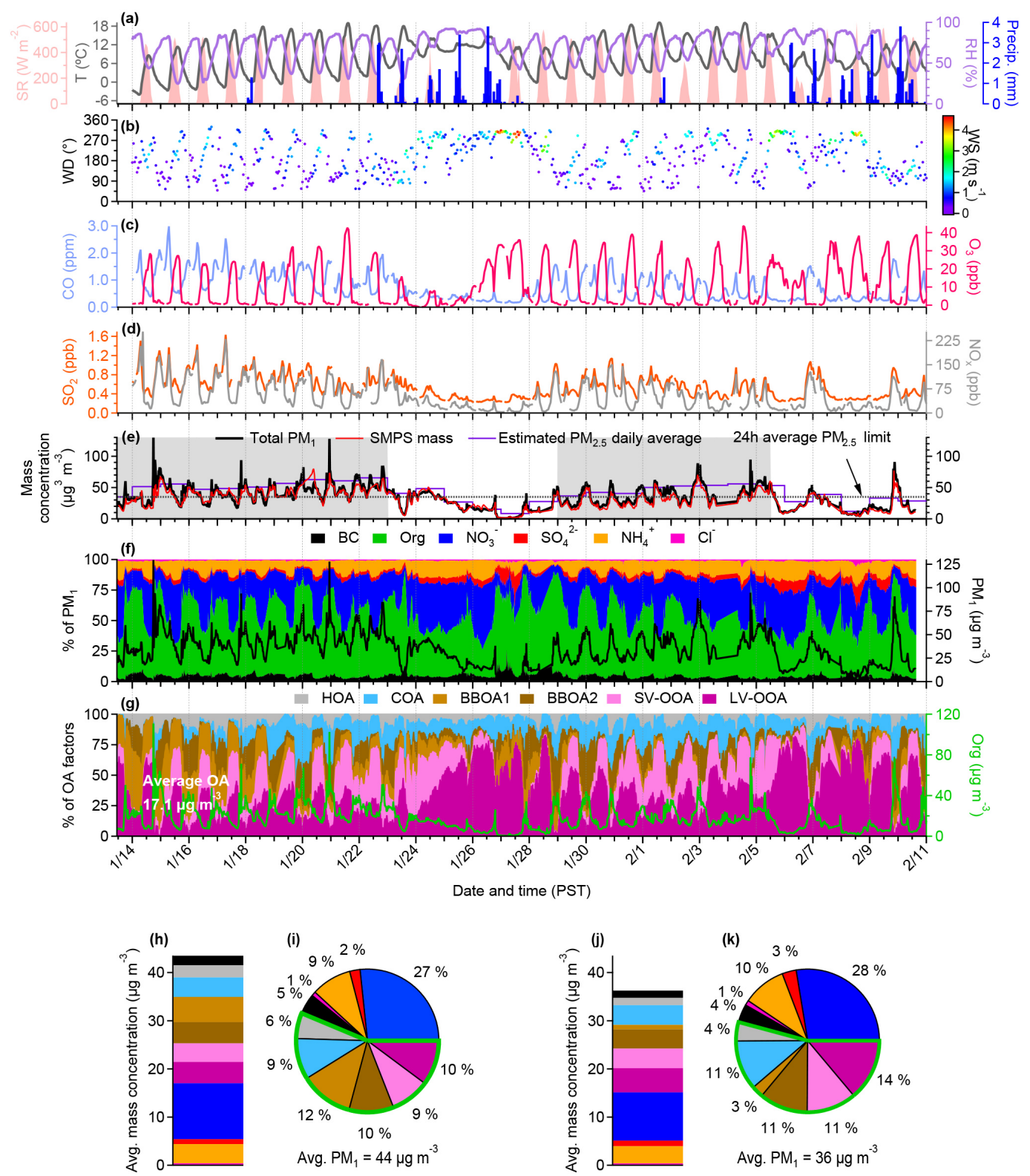

Figure 2. Overview of the chemical composition and temporal trends of submicron aerosols at Fresno in the San Joaquin Valley in January and February 2013 including (a) time series of ambient air temperature ( $T$ ), relative humidity (RH), solar radiation (SR), and precipitation (Precip.); (b) time series of wind direction (WD) colored by wind speed (WS); (c) time series of gas-phase pollutants $\left(\mathrm{CO}\right.$ and $\left.\mathrm{O}_{3}\right)$; (d) time series of gas-phase pollutants $\left(\mathrm{SO}_{2}\right.$ and $\left.\mathrm{NO}_{x}\right)$; (e) time series of total $\mathrm{PM}_{1}$ and SMPS mass concentrations where SMPS mass was calculated using a time-varying density based on measured particle composition (see Fig. S1b). Also shown are the $24 \mathrm{~h}$ average National Ambient Air Quality Standard for $\mathrm{PM}_{2.5}\left(35 \mu \mathrm{g} \mathrm{m}^{-3}\right)$ and the calculated average daily $\mathrm{PM}_{2.5}$ concentrations for comparison. Persistent exceedances of this standard characterize the two pollution periods highlighted by gray shading (14-23 January and 29 January-5 February); (f) time series of the mass fractional contribution of organic aerosols (Org.), nitrate $\left(\mathrm{NO}_{3}^{-}\right)$, sulfate $\left(\mathrm{SO}_{4}^{2-}\right)$, ammonium $\left(\mathrm{NH}_{4}^{+}\right)$, chloride $\left(\mathrm{Cl}^{-}\right)$, and $\mathrm{BC}$ to total $\mathrm{PM}_{1}$ and time series of the total $\mathrm{PM}_{1}$ concentration on the right axis; and (g) time series of the mass fractional contribution to total organic aerosol (OA) of the six factors derived from PMF analysis (see Sect. 3.2) and the time series of the organic aerosols. (h) Average mass concentration of the $\mathrm{PM}_{1}$ species during the first polluted period. The organic aerosol fraction has been split into its components as derived from PMF analysis; (i) compositional pie chart of the $\mathrm{PM}_{1}$ species from the first polluted period, where the total organic fraction is outlined in green; $(\mathbf{j})$ average mass concentration of the $\mathrm{PM}_{1}$ species during the second polluted period. The organic aerosol fraction has been split into its components as derived from PMF analysis; (k) compositional pie chart of the $\mathrm{PM}_{1}$ species from the second polluted period, where the total organic fraction is outlined in green. 
Table 1. Average ( \pm 1 standard deviation), minimum and maximum concentrations of the $\mathrm{PM}_{1}$ species and the total $\mathrm{PM}_{1}$ mass over the whole campaign, and the average contribution of each of the $\mathrm{PM}_{1}$ species to the total $\mathrm{PM}_{1}$ mass.

\begin{tabular}{lllll}
\hline & $\begin{array}{l}\text { Average concentration } \\
\pm 1 \text { standard deviation }\left(\mu \mathrm{g} \mathrm{m}^{-3}\right)\end{array}$ & $\begin{array}{l}\text { Minimum } \\
\text { concentration }\left(\mu \mathrm{g} \mathrm{m}^{-3}\right)\end{array}$ & $\begin{array}{l}\text { Maximum } \\
\text { concentration }\left(\mu \mathrm{g} \mathrm{m}^{-3}\right)\end{array}$ & $\begin{array}{l}\text { Fraction of total } \mathrm{PM}_{1} \\
\pm 1 \text { standard deviation }(\%)\end{array}$ \\
\hline Organics & $17.1 \pm 12.2$ & 0.38 & 111 & $55 \pm 39$ \\
Nitrate & $8.23 \pm 5.38$ & 0.08 & 28.0 & $27 \pm 17$ \\
Sulfate & $0.97 \pm 0.57$ & 0.10 & 3.47 & $3 \pm 2$ \\
Ammonium & $2.94 \pm 1.82$ & 0.03 & 9.08 & $9 \pm 6$ \\
Chloride & $0.34 \pm 0.26$ & 0.001 & 3.29 & $1 \pm 1$ \\
Black carbon & $1.48 \pm 0.93$ & 0.07 & 8.32 & $5 \pm 3$ \\
Total $\mathrm{PM}_{1}$ & $31.0 \pm 17.6$ & 0.70 & 130 & - \\
\hline
\end{tabular}
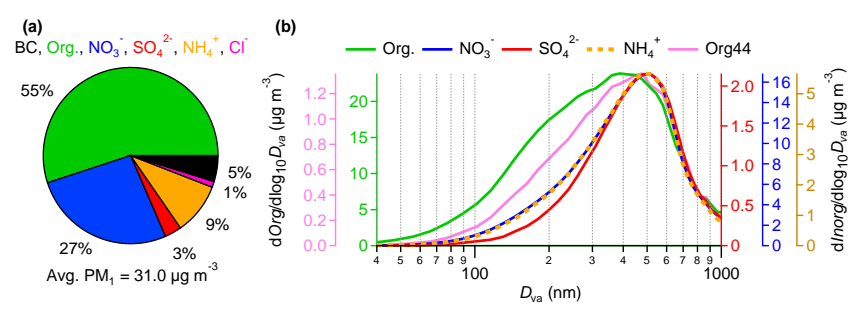

Figure 3. (a) Average compositional pie chart of $\mathrm{PM}_{1}$ species (nonrefractory $\mathrm{PM}_{1}$ plus $\mathrm{BC}$ ) for the whole campaign; (b) campaign-

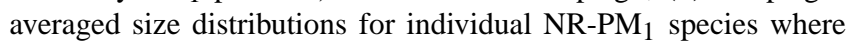
Org44 is used to represent secondary organic aerosols. The organic aerosol distribution has been smoothed using the binomial smooth algorithm within Igor.

In terms of mass-based size distributions, OA exhibited a broad size distribution, peaking between 350 and $450 \mathrm{~nm}$ in vacuum aerodynamic diameter $\left(D_{\mathrm{va}}\right)$ (Fig. $\left.3 \mathrm{~b}\right)$. The mode of OA size distribution varied as a function of time of day (Fig. 4g and Fig. S7a); a narrower size distribution peaking at $\sim 400 \mathrm{~nm}$ is observed during the day with a broadening and shifting to smaller sizes from the evening and into the morning. Nitrate, sulfate, and ammonium all peaked in size close to $D_{\text {va }}$ of $500 \mathrm{~nm}$ (Fig. 3b) and the peak size varied little across the day (Fig. 4h-j and Fig. S7b-d). Differences in size distribution patterns between the organic and inorganic species suggest that the formation of secondary inorganic species were influenced by aqueous-phase processes, consistent with findings from a previous study in Fresno (Ge et al., 2012b). Both primary and secondary aerosols contribute to the broad size distribution of organics, with anthropogenic primary emissions predominantly from fossil fuel and biomass combustion emissions influencing the distribution in the morning and evening and secondary formation influencing the daytime size distributions.

\subsection{Organic aerosol characteristics and source apportionment}

\subsubsection{Bulk composition and elemental ratios of organic aerosol}

Organic aerosols are a complex mixture of hundreds of carbon-containing compounds that are emitted from different sources and have undergone different atmospheric processes. OA exhibit a range of properties and subsequently will have a number of impacts on air quality, human health, and climate. Understanding the elemental composition of OA and separating the organic fraction into its various components are both important in order to gain insight into the sources and atmospheric processing of particulate organics as well as the behavior and characteristics of the aerosols.

In winter 2013 at Fresno the OA fraction was found to be composed of approximately $68 \%$ carbon, $23 \%$ oxygen, $8 \%$ hydrogen, and $1 \%$ nitrogen (Fig. 5a). The average carbon-normalized molecular formula of $\mathrm{OA}$ was $\mathrm{C}_{1} \mathrm{H}_{1.7} \mathrm{O}_{0.42} \mathrm{~N}_{0.017} \mathrm{~S}_{0.0004}$, yielding an average OM / OC of 1.71. The $\mathrm{O} / \mathrm{C}$ and $\mathrm{H} / \mathrm{C}$ atomic ratios (Table $\mathrm{S} 1$ ) are similar to revised values observed at other urban locations (Canagaratna et al., 2015, and references within). The influence of anthropogenic emissions is evident in the diurnal profile of the $\mathrm{H} / \mathrm{C}$ ratio (Fig. 5b), which exhibits peaks at 08:00 and 20:00 PST, likely reflecting the morning and evening rush hours as well as evening meal times and residential heating. However, compared to nighttime, higher $\mathrm{O} / \mathrm{C}$ and lower $\mathrm{H} / \mathrm{C}$ ratios were observed during a large part of the day suggesting that production of SOA was prevalent during the day and outweighed emissions of primary organic aerosol (POA), with the converse true in the evening. The diurnal profile of the nitrogen-to-carbon $(\mathrm{N} / \mathrm{C})$ ratio is relatively similar to that of the $\mathrm{O} / \mathrm{C}$ ratio, suggesting that, although nitrogencontaining organic ions are scarce, the majority of the $\mathrm{N}$ in OA is likely associated with SOA in this study.

The largest component of the OA mass spectral signal was found to be the $\mathrm{C}_{x} \mathrm{H}_{y}^{+}$ion family (47\%, Fig. 5a), followed by the $\mathrm{C}_{x} \mathrm{H}_{y} \mathrm{O}_{1}^{+}(31 \%)$ and $\mathrm{C}_{x} \mathrm{H}_{y} \mathrm{O}_{2}^{+}(15 \%)$ ion families and smaller contributions from the $\mathrm{C}_{x} \mathrm{H}_{y} \mathrm{~N}_{p}^{+}(3 \%), \mathrm{C}_{x} \mathrm{H}_{y} \mathrm{~N}_{p} \mathrm{O}_{z}^{+}$ 


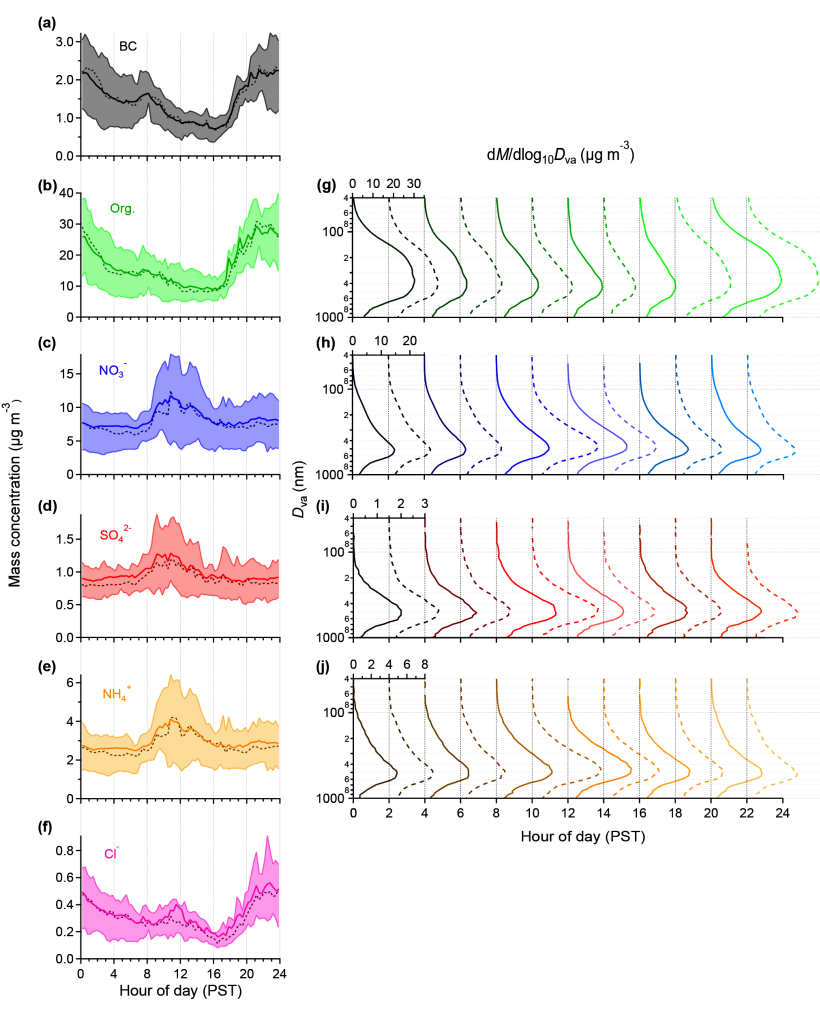

Figure 4. (a-f) Average diurnal profiles of each of the $\mathrm{PM}_{1}$ species where BC measurements are from the SP2 (the 75th and 25th percentiles are denoted by the top and bottom of the shaded region, the median values are denoted by the broken, dark colored lines, and the mean values are denoted by the solid, light-colored lines); (g-j) $2 \mathrm{~h}$ average diurnal size distributions for each of the NR-PM $\mathrm{P}_{1}$ species. The size distribution of chloride is not included here due to its low signal-to-noise ratio. The vertical grid lines indicate the zero line for each of the $2 \mathrm{~h}$ averaged mass-based size distributions and the starting hour of the averaging period (e.g., the zero line for the average size distribution for 06:00-08:00 PST is the vertical line at the $6 \mathrm{~h}$ tick). Each size distribution is scaled to the maximum mass range for that species, as indicated by the top axis for the 00:00-02:00 PST distribution. The organic aerosol distribution has been smoothed using the binomial smoothing algorithm within Igor. Mass-based diurnal size distributions between 30 and $1400 \mathrm{~nm}$, of NR-PM ${ }_{1}$ species, Org44, used to represent secondary organic aerosols, and Org41, used to represent hydrocarbon-containing aerosols, are shown in Fig. S7.

(2\%), and $\mathrm{H}_{y} \mathrm{O}_{1}^{+}(2 \%)$ ion families. The largest peak in the average OA spectrum is at $m / z 43$ (Fig. 5c), accounting for $8 \%$ of the total OA signal with a composition of $71 \%$ $\mathrm{C}_{2} \mathrm{H}_{3} \mathrm{O}^{+}, 27 \% \mathrm{C}_{3} \mathrm{H}_{7}^{+}, 1 \% \mathrm{CHON}^{+}$, and $1 \% \mathrm{C}_{2} \mathrm{H}_{5} \mathrm{~N}^{+}$. The second largest peak in the average OA spectrum is $m / z 44$, which is dominated by the $\mathrm{CO}_{2}^{+}$ion $(84 \%)$. The peak at $m / z 60$ is composed almost entirely of $\mathrm{C}_{2} \mathrm{H}_{4} \mathrm{O}_{2}^{+}(98 \%)$ and $88 \%$ of the peak at $m / z 73$ is composed of $\mathrm{C}_{3} \mathrm{H}_{5} \mathrm{O}_{2}^{+}$. The strong signals at $m / z$ s 60 and 73 are of particular interest as they are known fragment ions in the electron impact mass spectrum of levoglucosan and anhydrous sugars, which are all tracers of biomass burning aerosol (Alfarra et al., 2007; Aiken et al., 2008). $m / z$ 57, which is used as a tracer for HOA for urban data sets (Zhang et al., 2005a) and noted as a main fragment ion of levoglucosan (Schneider et al., 2006), is composed predominantly of $\mathrm{C}_{4} \mathrm{H}_{9}^{+}(50 \%)$ and $\mathrm{C}_{3} \mathrm{H}_{5} \mathrm{O}^{+}$ $(48 \%)$ in this study.

Separation of the organic fraction into its components can be achieved through the application of multivariate models such as PMF (Lanz et al., 2007; Ulbrich et al., 2009; Zhang et al., 2011). In this study, six OA factors were identified from PMF analysis of the high-resolution organic mass spectra consisting of four POA factors (HOA, COA, BBOA1, and BBOA2) and two SOA factors (LV-OOA and SV-OOA). An overview of the chemical composition and temporal variations of the six factors is shown in Fig. 6. LV-OOA (24\%) represents the largest fraction of OA mass and the smallest faction of OA is accounted for by HOA ( $9 \%)$. COA, BBOA1, BBOA2, and SV-OOA, on average, account for 18, 13, 20, and $16 \%$ of the total OA mass, respectively. On average, the primary components together account for $\sim 60 \%$ of the total OA mass in Fresno during winter 2013 (Fig. 6s) and LVOOA accounts for $\sim 60 \%$ of the total SOA mass. The chemical composition, size distribution, and temporal variations of each factor are discussed in detail in Sects. 3.2.2-3.2.5.

\subsubsection{Hydrocarbon-like OA}

The $\mathrm{O} / \mathrm{C}$ ratio of the HOA in this study is low (0.09) whereas the $\mathrm{H} / \mathrm{C}$ ratio is very high (2.10), indicating that chemically reduced hydrocarbon species dominate the composition. This is confirmed by the HOA mass spectrum which is dominated by the $\mathrm{C}_{x} \mathrm{H}_{y}^{+}$ion family (85\%, Fig. 6a), with major peaks at $m / z \mathrm{~s} 41,43,55$, and 57 that comprise signals from the $\mathrm{C}_{3} \mathrm{H}_{5}^{+}, \mathrm{C}_{3} \mathrm{H}_{7}^{+}, \mathrm{C}_{4} \mathrm{H}_{7}^{+}$, and $\mathrm{C}_{4} \mathrm{H}_{9}^{+}$ions, respectively. These major peaks and the overall picket fence fragmentation pattern resulting from the $\mathrm{C}_{n} \mathrm{H}_{2 n+1}^{+}$ions are typical in HOA mass spectra from other studies due to the association of these aerosols with fossil fuel combustion activities (e.g., Zhang et al., 2005a; Lanz et al., 2008; Sun et al., 2011; Ge et al., 2012a). In this study, the HOA mass spectrum agrees well with those from vehicle emission studies (e.g., $r=0.92-0.98$ for the correlations with spectra from Collier et al., 2015) (Fig. S8). HOA exhibits a relatively broad size distribution and peaks at the smallest size of all the OA factors at around $190 \mathrm{~nm}$ (Fig. 6u). The largest contribution of HOA to total OA is in the ultrafine mode $(<100 \mathrm{~nm}$; Fig. $6 \mathrm{v})$, which is the size associated with aerosols from combustion activities (Alfarra et al., 2004; Drewnick et al., 2004; Zhang et al., 2005a).

Strong correlations are observed between the time series of $\mathrm{HOA}$ and the $\mathrm{C}_{n} \mathrm{H}_{2 n \pm 1}^{+}$ions, e.g., $\mathrm{C}_{3} \mathrm{H}_{7}^{+}(r=0.92), \mathrm{C}_{4} \mathrm{H}_{7}^{+}$ $(r=0.90), \mathrm{C}_{4} \mathrm{H}_{9}^{+}(r=0.95)$, and $\mathrm{C}_{5} \mathrm{H}_{11}^{+}(r=0.96)$ (Table 2). The time series of HOA correlates well with tracers for vehicular emissions, particularly aromatic species such as benzene and toluene ( $r=0.83$ and 0.75 , respectively; Fig. $6 \mathrm{~g}$ and Ta- 

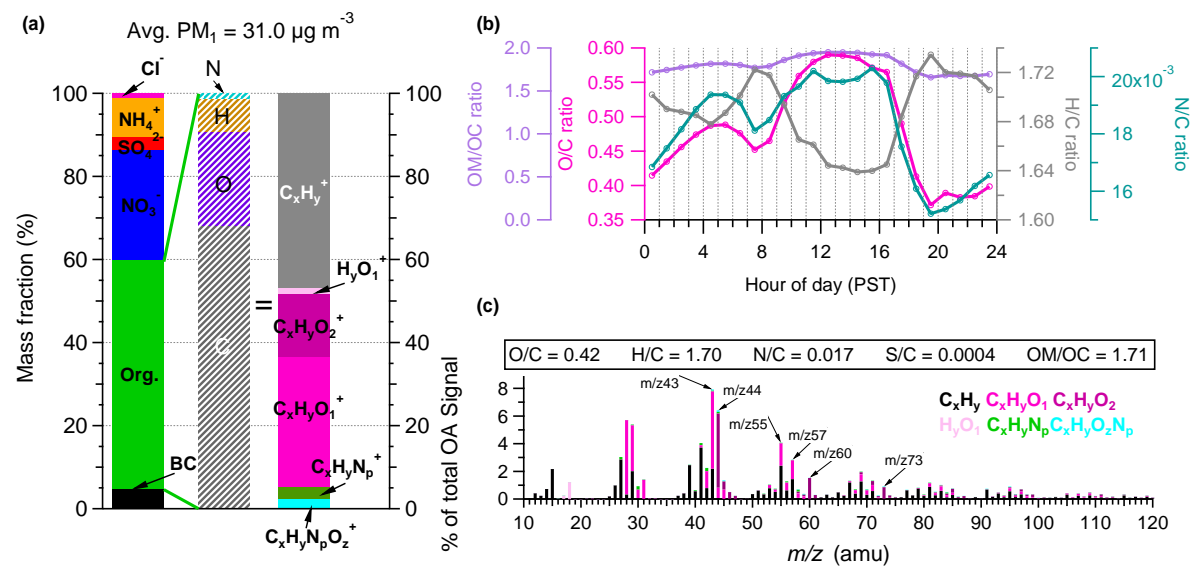

Figure 5. (a) Overview of the average $\mathrm{PM}_{1}$ and $\mathrm{OA}$ compositions in Fresno 2013; (b) average diurnal profiles of the oxygen-to-carbon (O / C), hydrogen-to-carbon (H / C), nitrogen-to-carbon (N / C), and organic-matter-to-organic-carbon (OM / OC) ratios of OA, where the $\mathrm{O} / \mathrm{C}, \mathrm{H} / \mathrm{C}$ and $\mathrm{OM} / \mathrm{OC}$ elemental ratios were determined using the improved-ambient method (Canagaratna et al., 2015); and (c) average high-resolution mass spectrum of OA colored by ion families. The average elemental ratios for the organic aerosol fraction are detailed in the box.

ble 2). Polar plots showing the concentration of a pollutant as a function of wind speed and direction also suggest similar local sources for HOA, benzene, and toluene as they have similar spatial distributions with the highest concentrations at low wind speeds (Fig. 7). The association of HOA and traffic is further supported by the diurnal profile of HOA, as shown in Fig. 6m, where concentrations peak at times corresponding to rush hour traffic. However, the morning peak at 07:00 PST is slightly earlier than that from a similar campaign performed in a nearby location in winter 2010 (Ge et al., 2012a), where the morning peak was observed between 08:00 and 10:00 PST. The evening peak is also relatively broad in the current study (18:00-00:00 PST) with a maximum at 22:00 PST, which is later than expected for a peak in rush hour traffic so may indicate that lower BL heights result in enhanced HOA concentrations at night.

\subsubsection{Cooking OA}

The COA in this study has an $\mathrm{O} / \mathrm{C}$ ratio of 0.19 , which is lower than the revised $\mathrm{O} / \mathrm{C}$ ratio for $\mathrm{COA}$ in Barcelona (0.27) and New York City (0.23) but is higher than the COA identified in Fresno in 2010 (0.14) (Table S3). The OM / OC ratio is 1.42 and the $\mathrm{H} / \mathrm{C}$ ratio is 1.90 . The mass-based size distribution of COA peaks in the accumulation mode at approximately $400 \mathrm{~nm}$ (Fig. 6u), greater than that of HOA and consistent with previous observations of COA size distributions (e.g., Canagaratna et al., 2004; Ge et al., 2012a), although a wide range of sizes of particles emitted from cooking activities can be observed due to the different methods of cooking, ingredients used, and distances from the cooking source. Compared to the other OA factors, the fractional contribution of COA to total OA does not vary as dramatically with size (Fig. 6v).
COA has been observed to be an important component of ambient aerosols in many urban locations (Allan et al., 2010; Sun et al., 2011; Mohr et al., 2012; Crippa et al., 2013) where $m / z \mathrm{~s} 55,57,41$, and 43 have been used as key $m / z$ s to identify the presence of aerosols from cooking-related activities. In addition, Sun et al. (2011) suggested that $\mathrm{C}_{5} \mathrm{H}_{8} \mathrm{O}^{+}$, $\mathrm{C}_{6} \mathrm{H}_{10} \mathrm{O}^{+}$, and $\mathrm{C}_{7} \mathrm{H}_{12} \mathrm{O}^{+}$are likely good tracer ions for COA. As the main peaks in the COA spectrum are also important in HOA, Mohr et al. (2012) developed a method for estimating COA in ambient data sets to a first order based on fractions of the organic signals at $m / z$ s 55 and 57 . When HRMS data are available the $\mathrm{C}_{3} \mathrm{H}_{3} \mathrm{O}^{+}$and $\mathrm{C}_{3} \mathrm{H}_{5} \mathrm{O}^{+}$ions at $m / z s 55$ and 57 may be used; $\mathrm{C}_{3} \mathrm{H}_{3} \mathrm{O}^{+}$is typically observed to dominate the signal at $m / z 55$ compared to $\mathrm{C}_{4} \mathrm{H}_{7}^{+}$ in COA with the converse true for HOA. However, BBOA and OOA can also contribute to the signal at $\mathrm{m} / z 55$ and in this study the total BBOA contributes $34 \%$ to the $\mathrm{C}_{3} \mathrm{H}_{3} \mathrm{O}^{+}$ ion $(\mathrm{BBOA} 1=13 \%, \mathrm{BBOA} 2=21 \%)$, whereas $\mathrm{COA}$ only contributes $29 \%$ (Fig. S9); thus the method to distinguish between HOA and COA developed by Mohr et al. (2012) may not be particularly useful here due to the influence from BBOA. However, COA contains a greater proportion of oxygen-containing ions such as $\mathrm{C}_{x} \mathrm{H}_{y} \mathrm{O}_{1}^{+}$and $\mathrm{C}_{x} \mathrm{H}_{y} \mathrm{O}_{2}^{+}$ than HOA, which contribute a total of $29.5 \%$ to $\mathrm{COA}$ and only $10.5 \%$ to HOA (Fig. S10).

The diurnal pattern of COA exhibits a large evening peak, with a maximum concentration at 19:00 PST which gradually decreases during the night (Fig. 6n). The evening peak is likely associated with dinnertime cooking activities, although this could be enhanced due to influences from residential wood combustion activities. As the COA from a campaign in Fresno during winter 2010 (Ge et al., 2012a) appears to be less influenced by BBOA, the COA mass spectrum from Ge et al. (2012a) is used to estimate the con- 

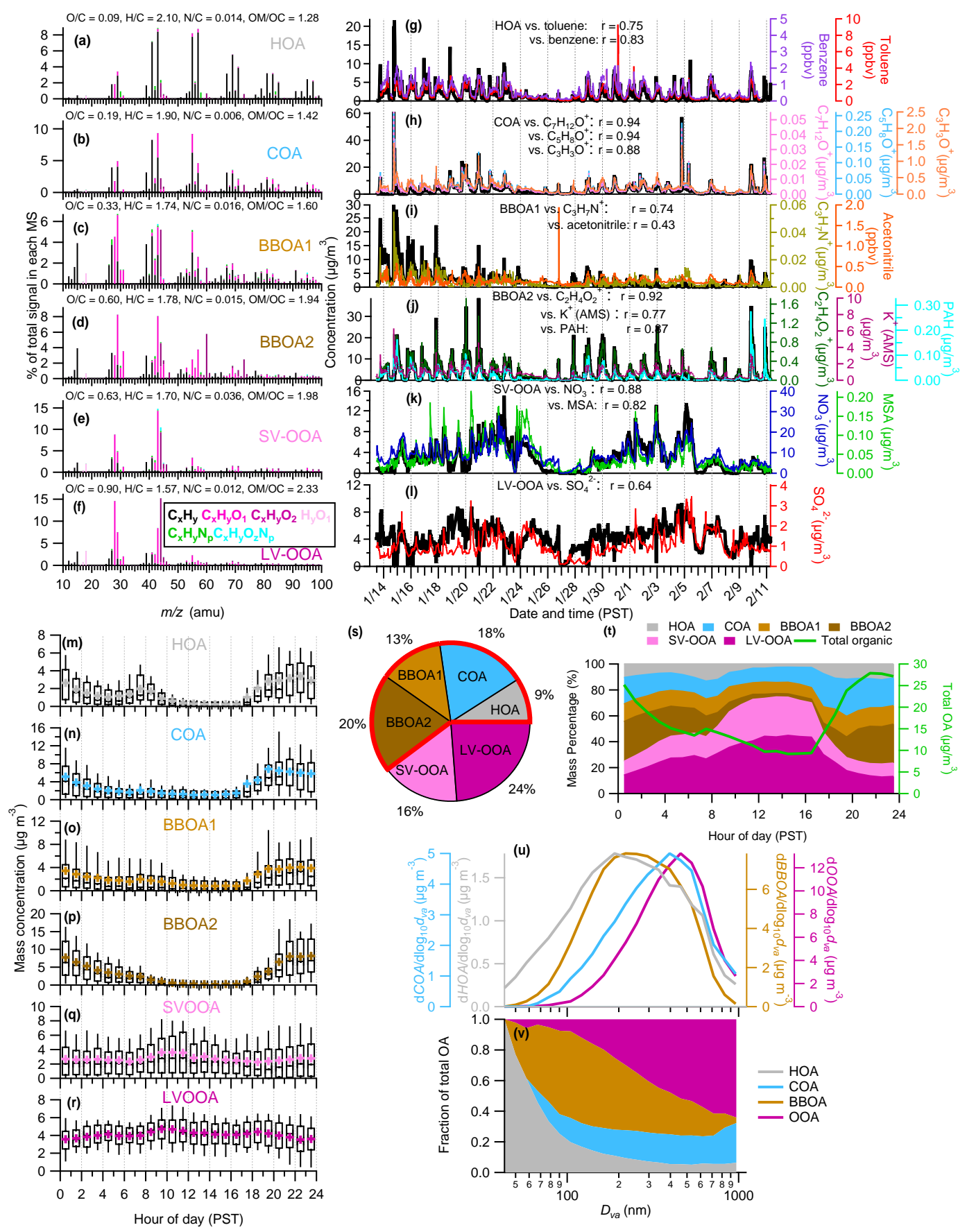

$\begin{array}{ll}\text { (t) } & \text { HOA COA BBOA1 BBOA2 } \\ \text { SV-OOA LV-OOA Total organic }\end{array}$
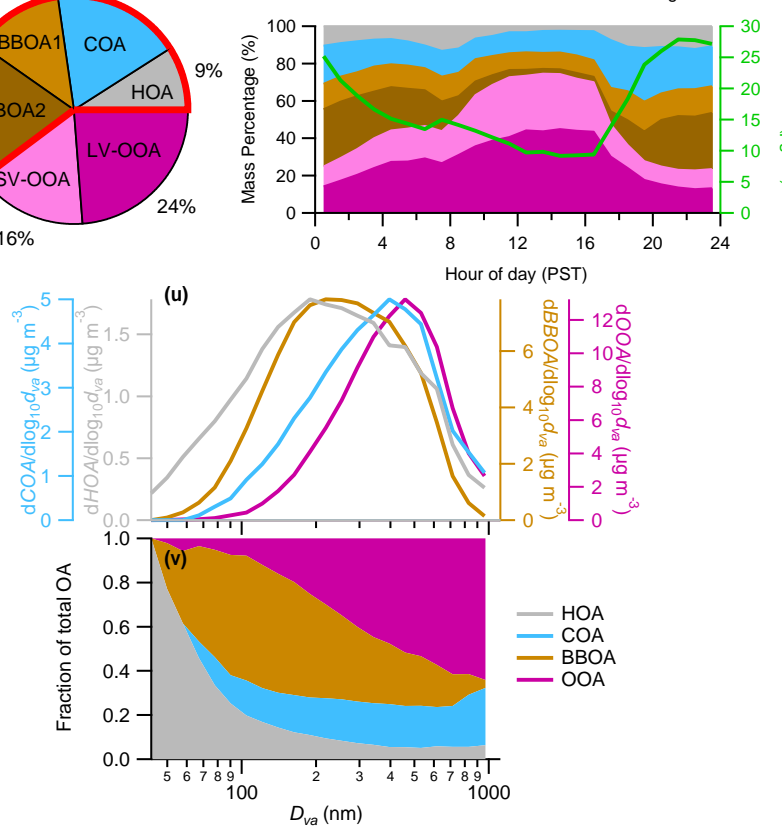

Figure 6. Overview of the results from positive matrix factorization (PMF) analysis including high-resolution mass spectra of the (a) hydrocarbon-like OA (HOA), (b) cooking OA (COA), (c) biomass burning OA 1 (BBOA1), (d) biomass burning OA 2 (BBOA2), (e) semivolatile oxygenated OA (SV-OOA), and (f) low-volatility oxygenated OA (LV-OOA) colored by different ion families; (g-l) time series of each of the OA factors and various tracer species; (m-r) average diurnal profiles of each of the OA factors (the 90th and 10th percentiles are denoted by the whiskers above and below the boxes, the 75th and 25th percentiles are denoted by the top and bottom of the boxes, the median values are denoted by the horizontal line within the box, and the mean values are denoted by the colored markers); (s) compositional pie chart of the average fractional contribution of each of the OA factors to the total OA for the campaign. The POA factors are outlined in red. (t) Average diurnal mass fractional contribution of each of the OA factors to the total OA diurnal and the total OA mass loading; and (u) average size distributions of the OA factors where BBOA1 and BBOA2 were summed together to BBOA before performing the analysis. Similarly, SV-OOA and LV-OOA were also summed to OOA before performing the analysis. (v) Average mass fractional contributions of the $\mathrm{OA}$ components to the total $\mathrm{OA}$ mass as a function of size. 



Figure 7. Polar plots of hourly averaged $\mathrm{PM}_{1}$ species concentrations (top row), mass concentrations of the six OA factors identified from PMF analysis (middle row), and mixing ratios of various gas-phase species from the CARB monitoring station as well as acetonitrile and benzene VOCs measured by the PTR-TOF-MS (bottom row) as a function of wind speed and direction. These polar plots were plotted in $R$ using the openair package (Carslaw and Ropkins, 2012; Carslaw, 2015), a data analysis tool for investigating air pollution.

tribution of BBOA to COA in 2013. The resulting mass spectrum exhibits characteristics of BBOA (Fig. S11a) and contributes approximately $20 \%$ to COA in 2013 . The diurnal profile of COA with the estimated BBOA influence removed is compared to that of the COA retrieved from PMF analysis (Fig. S11b); the concentrations during the night are reduced in the profile without the BBOA influence but a lunchtime peak is still not evident in 2013. Nevertheless, the time series of COA correlates well with the $\mathrm{C}_{3} \mathrm{H}_{3} \mathrm{O}^{+}$ $(r=0.88)$ and $\mathrm{C}_{7} \mathrm{H}_{12} \mathrm{O}^{+}(r=0.94)$ ions (Fig. 6h and Table 2) as well as with $\mathrm{C}_{6} \mathrm{H}_{10} \mathrm{O}^{+}(r=0.92)$ and $\mathrm{C}_{5} \mathrm{H}_{8} \mathrm{O}^{+}$ $(r=0.94)$. COA also contributes $56 \%, 69 \%$, and $64 \%$ to the $\mathrm{C}_{5} \mathrm{H}_{8} \mathrm{O}^{+}, \mathrm{C}_{6} \mathrm{H}_{10} \mathrm{O}^{+}$, and $\mathrm{C}_{7} \mathrm{H}_{12} \mathrm{O}^{+}$ions, respectively (Fig. S9). These observations thus support the identification of this factor as COA.

\subsubsection{Biomass burning OA (BBOA1 and BBOA2)}

Residential space heating is recognized as an important source of aerosols in many locations, especially in urban locations where BBOA and solid fuel OA factors have been identified in source apportionment studies (Lanz et al., 2007; Aiken et al., 2009; Allan et al., 2010; Ge et al., 2012a; Mohr et al., 2012; Xu et al., 2015; Young et al., 2015a, b). BBOA is typically associated with wood combustion and is preva- lent during the winter in the SJV (Chow et al., 2006; Chen et al., 2007; Ge et al., 2012a). The importance of biomass burning emissions in this area is further highlighted as two BBOA factors were derived from PMF analysis of OA, together contributing $33 \%$ to the total OA. According to the polar plots showing potential source influences, high concentrations of both BBOA1 and BBOA2 occur at low wind speeds (Fig. 7) indicating emissions likely arise from similar local activities rather than being transported to the site. This is further indicated by the mass-based size distribution of total BBOA, which is more similar to that of HOA than the OOAs. The total BBOA size distribution peaks in the accumulation mode, at $220 \mathrm{~nm}$ (Fig. 6u). In addition, BBOA dominates the mass fraction of OA at small sizes, particularly at $100<D_{\mathrm{va}}<200 \mathrm{~nm}$ (Fig. 6v), supporting the association of these aerosols with combustion activities.

As the chemical composition of ambient BBOA is found to be highly variable (DeCarlo et al., 2010; Parworth et al., 2015), multiple BBOA factors identified from factorization analyses could represent differences in the degree of atmospheric processing (e.g., Brito et al., 2014), combustion conditions (e.g., Young et al., 2015b), and fuel types. Both BBOA mass spectra contain enhanced biomass burning tracer peaks at $m / z=60\left(\right.$ mostly $\mathrm{C}_{2} \mathrm{H}_{4} \mathrm{O}_{2}^{+}$) and 73 (mostly $\mathrm{C}_{3} \mathrm{H}_{5} \mathrm{O}_{2}^{+}$) (Fig. $6 \mathrm{c}$ and d) but $m / z=60$ and 73 contribute 
Table 2. Correlation coefficient (Pearson's $r$ ) for linear regressions between OA factors (including the sum of both BBOA factors as well as the sum of the OOA factors) and various particle- and gas-phase species and ions.

\begin{tabular}{|c|c|c|c|c|c|c|c|c|}
\hline$r$ & $\mathrm{HOA}$ & $\mathrm{COA}$ & BBOA1 & BBOA2 & $\begin{array}{r}\text { BBOA1 } \\
+ \\
\text { BBOA2 }\end{array}$ & SV-OOA & LV-OOA & $\begin{array}{r}\text { SV-OOA } \\
+ \\
\text { LV-OOA }\end{array}$ \\
\hline Nitrate & 0.14 & 0.15 & 0.16 & 0.00 & 0.08 & 0.88 & 0.59 & 0.88 \\
\hline Sulfate & 0.04 & 0.08 & -0.05 & -0.08 & -0.08 & 0.74 & 0.64 & 0.80 \\
\hline Ammonium & 0.13 & 0.14 & 0.14 & -0.01 & 0.06 & 0.87 & 0.62 & 0.89 \\
\hline Chloride & 0.53 & 0.43 & 0.42 & 0.56 & 0.58 & 0.40 & 0.25 & 0.39 \\
\hline Org60 & 0.73 & 0.67 & 0.54 & 0.93 & 0.89 & 0.09 & -0.02 & 0.05 \\
\hline $\mathrm{CO}_{2}^{+}(\mathrm{AMS})$ & 0.48 & 0.54 & 0.39 & 0.43 & 0.48 & 0.77 & 0.64 & 0.83 \\
\hline K (AMS) & 0.76 & 0.73 & 0.60 & 0.77 & 0.81 & 0.43 & 0.22 & 0.40 \\
\hline PAH & 0.72 & 0.60 & 0.61 & 0.87 & 0.89 & -0.05 & -0.18 & -0.12 \\
\hline $\mathrm{BC}$ & 0.76 & 0.58 & 0.60 & 0.79 & 0.83 & 0.24 & 0.06 & 0.19 \\
\hline $\mathrm{CO}$ & 0.81 & 0.48 & 0.64 & 0.69 & 0.76 & 0.19 & -0.03 & 0.12 \\
\hline $\mathrm{NO}_{x}$ & 0.81 & 0.45 & 0.61 & 0.64 & 0.71 & 0.16 & -0.07 & 0.08 \\
\hline Acetonitrile & 0.62 & 0.51 & 0.43 & 0.61 & 0.61 & 0.15 & 0.05 & 0.12 \\
\hline Benzene & 0.83 & 0.58 & 0.59 & 0.77 & 0.79 & 0.14 & -0.02 & 0.09 \\
\hline Toluene & 0.75 & 0.53 & 0.43 & 0.64 & 0.63 & 0.22 & 0.05 & 0.18 \\
\hline Acetaldehyde & 0.64 & 0.50 & 0.51 & 0.43 & 0.53 & 0.47 & 0.15 & 0.39 \\
\hline Acetic acid & 0.41 & 0.36 & 0.49 & 0.28 & 0.42 & 0.29 & 0.03 & 0.22 \\
\hline Acetone & 0.33 & 0.35 & 0.19 & 0.23 & 0.24 & 0.31 & 0.19 & 0.30 \\
\hline Methanol & 0.46 & 0.42 & 0.36 & 0.30 & 0.37 & 0.36 & 0.13 & 0.30 \\
\hline Acetone/propanol & 0.29 & 0.33 & 0.12 & 0.20 & 0.19 & 0.29 & 0.20 & 0.29 \\
\hline $\mathrm{C}_{8}$ alkylbenzenes & 0.76 & 0.54 & 0.44 & 0.61 & 0.62 & 0.23 & 0.05 & 0.18 \\
\hline $\mathrm{C}_{9}$ alkylbenzenes & 0.75 & 0.54 & 0.35 & 0.60 & 0.57 & 0.24 & 0.05 & 0.19 \\
\hline Isoprene & 0.83 & 0.61 & 0.51 & 0.72 & 0.72 & 0.24 & -0.03 & 0.15 \\
\hline MVK/MACR* & 0.77 & 0.58 & 0.40 & 0.64 & 0.62 & 0.26 & 0.05 & 0.21 \\
\hline Monoterpenes & 0.73 & 0.52 & 0.53 & 0.71 & 0.73 & 0.19 & -0.01 & 0.12 \\
\hline $\mathrm{C}_{2} \mathrm{H}_{5} \mathrm{~N}^{+}$ & 0.65 & 0.43 & 0.72 & 0.40 & 0.61 & 0.55 & 0.12 & 0.43 \\
\hline $\mathrm{C}_{3} \mathrm{H}_{3} \mathrm{O}^{+}$ & 0.79 & 0.88 & 0.58 & 0.77 & 0.81 & 0.40 & 0.21 & 0.38 \\
\hline $\mathrm{C}_{3} \mathrm{H}_{7}^{+}$ & 0.92 & 0.90 & 0.63 & 0.69 & 0.77 & 0.22 & 0.03 & 0.17 \\
\hline $\mathrm{C}_{3} \mathrm{H}_{7} \mathrm{~N}^{+}$ & 0.52 & 0.24 & 0.74 & 0.27 & 0.54 & 0.36 & 0.03 & 0.27 \\
\hline $\mathrm{C}_{4} \mathrm{H}_{7}^{+}$ & 0.90 & 0.92 & 0.60 & 0.66 & 0.74 & 0.29 & 0.08 & 0.24 \\
\hline $\mathrm{C}_{4} \mathrm{H}_{9}^{+}$ & 0.95 & 0.87 & 0.62 & 0.68 & 0.76 & 0.18 & -0.01 & 0.12 \\
\hline $\mathrm{C}_{5} \mathrm{H}_{11}^{+}$ & 0.96 & 0.85 & 0.62 & 0.68 & 0.76 & 0.18 & -0.01 & 0.12 \\
\hline $\mathrm{C}_{5} \mathrm{H}_{8} \mathrm{O}^{+}$ & 0.78 & 0.94 & 0.51 & 0.58 & 0.64 & 0.38 & 0.18 & 0.35 \\
\hline $\mathrm{C}_{6} \mathrm{H}_{10} \mathrm{O}^{+}$ & 0.80 & 0.92 & 0.55 & 0.53 & 0.63 & 0.19 & 0.04 & 0.15 \\
\hline $\mathrm{C}_{7} \mathrm{H}_{12} \mathrm{O}^{+}$ & 0.77 & 0.94 & 0.48 & 0.57 & 0.62 & 0.36 & 0.15 & 0.32 \\
\hline $\mathrm{C}_{9} \mathrm{H}_{7}^{+}$ & 0.82 & 0.74 & 0.72 & 0.90 & 0.96 & 0.18 & -0.05 & 0.10 \\
\hline $\mathrm{CHN}^{+}$ & 0.49 & 0.37 & 0.69 & 0.35 & 0.56 & 0.58 & 0.36 & 0.57 \\
\hline $\mathrm{CN}^{+}$ & 0.42 & 0.29 & 0.56 & 0.25 & 0.44 & 0.52 & 0.30 & 0.49 \\
\hline $\mathrm{CH}_{2} \mathrm{SO}_{2}^{+}$ & 0.01 & 0.07 & 0.00 & -0.11 & -0.08 & 0.80 & 0.47 & 0.77 \\
\hline $\mathrm{CH}_{3} \mathrm{SO}_{2}^{7}$ & 0.06 & 0.07 & 0.10 & -0.06 & 0.00 & 0.81 & 0.45 & 0.76 \\
\hline $\mathrm{CH}_{4} \mathrm{SO}_{2}^{+}$ & -0.01 & 0.02 & 0.05 & -0.10 & -0.05 & 0.77 & 0.44 & 0.73 \\
\hline
\end{tabular}

* MVK stands for methyl vinyl ketone and MACR stands for methacrolein.

less to the total BBOA1 signal (1.6 and $0.95 \%$, respectively) than to the total BBOA2 signal (5.8 and $2.5 \%$, respectively). This difference is particularly evident when the two factors are plotted in the triangular space used to investigate the BBOA evolution proposed by Cubison et al. (2011) (Fig. S12a). BBOA2 also has a higher $\mathrm{O} / \mathrm{C}$ ratio than BBOA1 (0.60 vs. 0.33; Fig. $6 \mathrm{c}$ and d), whereas the $\mathrm{C}_{x} \mathrm{H}_{y}^{+}$ ion family contributes more to BBOA1 than BBOA2 $(57.6 \%$ vs. $34.3 \%$; Fig. S10). The difference in oxidation (indicated by the $\mathrm{O} / \mathrm{C}$ ratio) and $f_{60}$ between the factors could therefore suggest different burning behaviors or fuel type. Indeed, a wide range of $\mathrm{O} / \mathrm{C}$ ratios for primary organic emissions from biomass burning has been observed in various studies (0.15-0.60; e.g., Heringa et al., 2011; Ortega et al., 2013) due to differences in burner type, combustion phases, and fuel types. 
The time series of BBOA1 and BBOA2 are compared with those of wood burning relevant species frequently used in the literature (Simoneit et al., 1999; Jordan et al., 2006; Otto et al., 2006; Aiken et al., 2009). Tracers such as acetonitrile are external measurements and are independent of the BBOA identification from PMF analysis whereas org60 is measured by the AMS and is used to identify BBOA factors. However, some biomass burning tracers measured by the AMS, such as polycyclic aromatic hydrocarbons (PAHs), are independent of the BBOA identification; PAHs are at $m / z \mathrm{~s}$ greater than 200 and PMF in this study was only performed on $\mathrm{m} / \mathrm{zs}$ up to 120 . BBOA1 correlates well with nitrogencontaining ions (Table 2), particularly $\mathrm{C}_{3} \mathrm{H}_{7} \mathrm{~N}^{+}(r=0.74)$ and $\mathrm{CHN}^{+}(r=0.69)$ (Fig. 6i), consistent with emissions of nitriles from biomass burning and combustion activities (Simoneit et al., 2003), although BBOA2 correlates more strongly with acetonitrile than BBOA1 ( $r=0.61$ vs. $r=0.43$ ), with similar polar plots of both factors and acetonitrile (Fig. 7). BBOA2 also has stronger correlations than BBOA1 with other biomass burning tracer species, including potassium $(r=0.86)$ and $\mathrm{BC}(r=0.79)$. Often used as tracers for biomass burning activities, PAHs are byproducts of incomplete combustion, many of which are mutagenic and carcinogens (Hannigan et al., 1998; Marr et al., 2006; Dzepina et al., 2007). Using the method described in Dzepina et al. (2007), total PAHs were estimated from the AMS; a stronger correlation is observed between BBOA2 and PAHs than BBOA1 ( $r=0.87$ compared to $r=0.61$ ). Consequently, adverse health effects associated with biomass burning emissions should be of great concern, especially during wintertime.

Both BBOA1 and BBOA2 have similar diurnal trends, with concentrations increasing overnight and low concentrations during the day. This diurnal behavior provides strong confidence that BBOA is associated with residential wood combustion for space heating. However, BBOA2 has a more distinct diurnal profile (Fig. 6o), with an especially large difference between daytime and nighttime concentrations, whereas the difference in BBOA1 concentrations between the day and night is not as large (Fig. 6p). Further, the greatest BBOA1 concentration occurs at the beginning of the campaign (Figs. 6i and j), which coincides with particularly low ambient temperatures (Fig. 2a). To investigate the influence of meteorology (in particular, temperature), the campaign is split into two periods: period 1 covers the beginning of the campaign up until 20 January and period 2 covers the remainder of the campaign. The first period was found to be colder than the rest of the campaign with an average temperature of $5.5^{\circ} \mathrm{C}$ and a minimum of $-4.1^{\circ} \mathrm{C}$ compared to an average of $8.7^{\circ} \mathrm{C}$ and a minimum of $-0.3^{\circ} \mathrm{C}$ for period 2 . During this first period, BBOA 1 contributes up to $60 \%$ to the total OA mass and averages $25 \%$ whereas BBOA2 only contributes an average of $15 \%$ to OA mass (Fig. $2 \mathrm{~g}$ ). BBOA is observed to dominate the composition of $\mathrm{PM}_{1}$ at low temperatures during the campaign (Fig. S13a); BBOA1 contributes
$22 \%$ and BBOA 2 contributes $14 \%$ at the very coldest temperatures, which occur over night and peak in the early morning (Fig. S13b). As this first period was particularly cold there may have been an increase in residential wood burning. Given these observations of differences in the temporal trends and the associated meteorological differences, it is likely that the two factors are associated with different burning behaviors, although we are unable to fully explain the differences between the two BBOA factors in terms of their sources.

\subsubsection{Low-volatility and semivolatile oxygenated $\mathrm{OA}$ (LV-OOA and SV-OOA)}

Two OOA factors were identified in this study, together accounting for $40 \%$ of the total OA mass (Fig. 6s). The mass spectra of both factors contain two major peaks at $\mathrm{CO}_{2}^{+}$ $(m / z=44)$ and $\mathrm{C}_{2} \mathrm{H}_{3} \mathrm{O}^{+}(\mathrm{m} / z=43)$ (Fig. 6e and f). Following analysis of thermodenuder data (not reported here), the more oxidized OOA $(\mathrm{O} / \mathrm{C}=0.90 ; \mathrm{H} / \mathrm{C}=1.57)$ is labeled as $\mathrm{LV}-\mathrm{OOA}$ and the less oxygenated factor $(\mathrm{O} / \mathrm{C}=0.63$; $\mathrm{H} / \mathrm{C}=1.70$ ) is labeled as SV-OOA. The O $/ \mathrm{C}$ ratio of $\mathrm{SV}$ OOA is higher than HOA and $\mathrm{COA}$ and the $\mathrm{O} / \mathrm{C}$ ratio of LV-OOA is significantly higher than those of the POA factors, consistent with observations that ambient primary OA tend to be less oxidized than secondary OA.

The secondary nature of OOA is further supported by the mass-based size distribution of the total OOA (Fig. 6u), which is similar to that of the secondary inorganics (Fig. 3b). The total OOA size distribution is the narrowest of all the OA factors and peaks at the largest $D_{\mathrm{va}}$ in the accumulation mode $(\sim 460 \mathrm{~nm})$, similar to that of OOA from 2010 (Ge et al., 2012a). The mass fraction of OOA increases with increasing particle size (Fig. 6v), contributing more than $50 \%$ to the total OA mass at sizes greater than approximately $500 \mathrm{~nm}$.

The $f_{44}$ vs. $f_{43}$ space ( $\mathrm{Ng}$ et al., 2010) is frequently used to describe and explain OA evolution in the atmosphere. In this study, LV-OOA falls within the region previously identified by Morgan et al. (2010) as corresponding to LV-OOA (Fig. S12b) and, although located outside of the triangle, SVOOA still falls within its respective region. All four POA factors identified in this study are located at the bottom left of the triangle thus are far from the two SOA factors, highlighting the differences in sources and precursors (as suggested by the $f_{43}$ values) and degree of oxygenation (as inferred from the $f_{44}$ values) between POA and SOA. Methanesulfonic acid (MSA) has been shown to be secondary in previous studies and is mostly the product of dimethyl sulfide oxidation (von Glasow and Crutzen, 2004). The AMS has successfully measured MSA in several studies, both over the ocean as well as in urban areas (e.g., Phinney et al., 2006; Zorn et al., 2008; Ge et al., 2012b). Consequently, the secondary nature of SV-OOA and LV-OOA is further supported by strong correlations observed with the AMS spectral ions for MSA (Table 2): $\mathrm{CH}_{2} \mathrm{SO}_{2}^{+}$( $r=0.80$ and 0.47 for SV-OOA 
and LV-OOA, respectively), $\mathrm{CH}_{3} \mathrm{SO}_{2}^{+}(r=0.81$ and 0.45$)$, and $\mathrm{CH}_{4} \mathrm{SO}_{2}^{+}$( $r=0.77$ and 0.44$)$.

The regional vs. local nature of SOA is often inferred from correlations with various tracers. As detailed in Table 2, SVOOA and LV-OOA correlate relatively strongly with nitrate $(r=0.88$ and 0.59 , respectively) and sulfate $(r=0.74$ and 0.64 , respectively). Sulfate is typically observed to be regional and nitrate is often formed more locally due to the emission patterns of their respective precursor gases thus SVOOA is likely more local whereas LV-OOA is likely to be more regional. Compared to the POA factors, which have local sources, the highest SOA concentrations are found at a larger range of wind speeds and directions (Fig. 7); however, SV-OOA appears to be influenced more by local emissions or events as high concentrations are associated with a smaller range of wind speeds and directions than LV-OOA. The diurnal profiles of SV-OOA and LV-OOA are similar with a midmorning peak in concentration (10:00-11:00 PST, Fig. 6q and $r$ ) yet the trend is more distinct for SV-OOA as LV-OOA concentrations are more constant throughout the day. These observations indicate the fresher, more localized nature of SV-OOA and the more aged and regional nature of LV-OOA.

The fractional contribution of SOA to total OA mass is greatest during the day whereas POA dominates in the evening until mid-morning (Fig. 6t), indicating the influence of boundary layer dynamics, local anthropogenic emissions, and photochemical activity. Furthermore, the contribution of LV-OOA to total OA mass also increases during two distinct periods of the campaign (24-28 January 2013 and 5-9 February 2013) (Fig. 2g) although the total organic aerosol concentration is relatively low. These periods are characterized by an average $\mathrm{RH}$ of $80 \%$. Furthermore the $\mathrm{RH}$ is greater than $90 \%$ for $15 \%$ of this time compared to a frequency of only $0.4 \%$ for the other times suggesting that aqueous-phase processing may have influenced the production of secondary aerosol species (Dall'Osto et al., 2009; Ge et al., 2012b), leading to increased LV-OOA concentrations during humid periods.

\subsection{Comparison of weekday and weekend diurnal profiles and insights into PM sources}

Diurnal profiles can provide insight into aerosol sources as well as atmospheric processes and dynamics. As many aerosol sources can be anthropogenic, comparing the diurnal profiles between the weekdays and weekends can help to separate the influence of different sources and processes on the temporal variations in the aerosol concentrations. Weekdays can be considered to be Monday to Friday, inclusive, while Saturday and Sunday are weekends. However, as the concentrations of some species, particularly secondary species like nitrate, may be controlled by emissions from the previous day (e.g., $\mathrm{NO}_{x}$ ), an alternative classification where Tuesday to Friday, inclusive, were considered weekdays and only Sunday as a weekend (Fig. S14a and b) was also used for examining the diurnal profiles. Since little difference in the trends is observed in the diurnal profiles between the two classifications, the Monday-Friday and Saturday-Sunday definitions are used for the following analyses.

The weekday and weekend diurnal profiles for $\mathrm{PM}_{1}$ species, the six OA factors from PMF analysis, several VOC species, as well as various gas-phase species and meteorological parameters are shown in Fig. 8 (also see Fig. S15). As expected, the diurnal variations in meteorology do not change significantly from the weekdays to the weekends. The diurnal pattern of COA only varies slightly between weekdays and weekends; weekend concentrations are slightly higher than those during the week, which could be due to people continuing their cooking activities longer into the evenings. Similarly, BBOA2 differs a little between the weekdays and weekends, with slightly higher concentrations in the evenings at weekends. Acetonitrile exhibits similar diurnal variations to that of BBOA2. In contrast, the concentration of BBOA1 is greater during the week than on the weekend, with concentrations approximately a factor of 2 greater, particularly during the morning. However, these results are likely skewed by the first week of particularly cold temperatures, which is evident when the diurnal profiles for the weekdays and weekend days for the first week are compared with those from the remaining 3 weeks (Fig. S16). Such temperatures likely lead to an increase in burning activities. Biomass burning likely influences chloride concentrations, as is evident from the similarity of the diurnal profiles as well as the strong correlations between chloride and total BBOA $(r=0.58$, Table 2) and biomass burning tracers potassium and acetonitrile ( $r=0.67$ and 0.51 , respectively; not shown here).

Differences in weekday and weekend diurnal variations can also be attributed to changes in anthropogenic behavior. For example, it is clear that HOA is associated with traffic as the morning rush hour peak is only evident in the weekday diurnal and the evening peak in concentration is slightly reduced at the weekends (Figs. 8 and S15). This is also the case for $\mathrm{NO}_{x}, \mathrm{CO}$, and $\mathrm{BC}$, which are all fossil fuel combustion tracers. In addition, the diurnal profiles of VOCs associated with vehicle emissions such as benzene and toluene on weekdays and weekends are similar to that of HOA. The diurnal profiles of isoprene are also similar to HOA indicating that isoprene may be associated with vehicle emissions. Previous studies report the predominance of anthropogenic sources of isoprene in urban areas during winter (Borbon et al., 2001; Seco et al., 2013); however, other hydrocarbons (e.g., cycloalkanes) could also be contributing to the PTRMS signal at the $m / z$ assigned to isoprene (e.g., Yuan et al., 2014). Odd oxygen $\left(\mathrm{O}_{x}=\mathrm{O}_{3}+\mathrm{NO}_{2}\right)$ is used here to examine the differences between weekdays and weekends rather than $\mathrm{O}_{3}$ due to the influence of $\mathrm{NO}_{x}$ on $\mathrm{O}_{3}$ concentrations (Herndon et al., 2008); $\mathrm{O}_{3}$ is observed to be lower during the weekdays due to titration by $\mathrm{NO}$ whereas $\mathrm{NO}_{x}$ is lower at the weekends and thus $\mathrm{O}_{3}$ concentrations are higher. The diurnal 

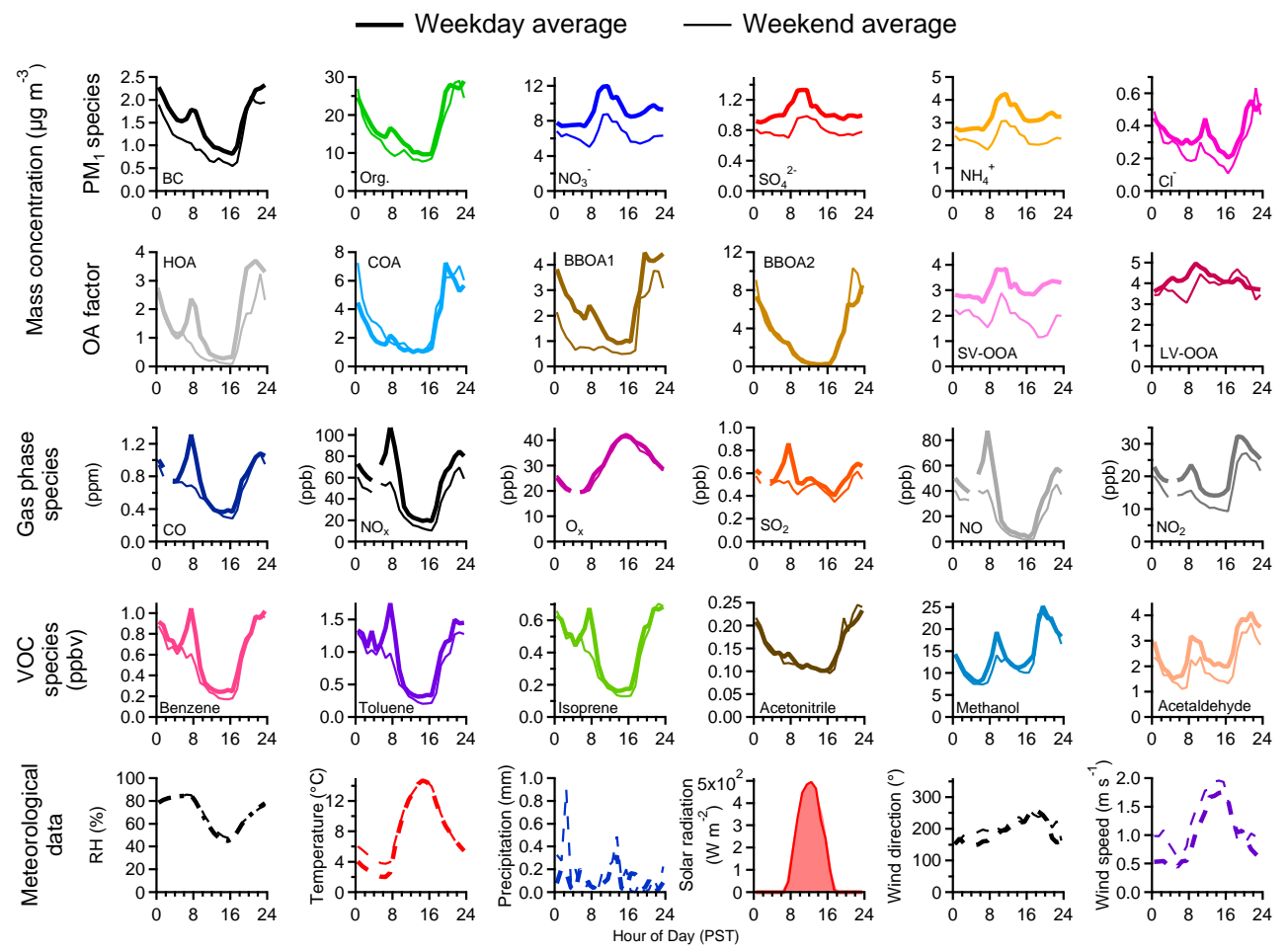

Figure 8. Average diurnal profiles for weekdays (Monday to Friday inclusive) and weekends (Saturday and Sunday) for the $\mathrm{PM}_{1} \mathrm{species}$ measured by the AMS and SP2 (top row), the six OA factors identified from PMF analysis (second row from the top), various gas-phase species from the CARB monitoring station (middle row), several VOCs measured by the PTR-MS (second row from the bottom), and various meteorological parameters (bottom row). The average diurnal profiles along with the standard deviations for all species for weekdays and weekends are shown in Fig. S15.

profile of $\mathrm{O}_{x}$ is therefore comparable between weekday and weekends. $\mathrm{SO}_{2}$ also exhibits a similar trend with a prominent morning peak only on weekdays, indicating that traffic is a main source of $\mathrm{SO}_{2}$ in Fresno. Indeed, the $\mathrm{SO}_{2}$ diurnal profiles between weekdays and weekends with those associated with traffic combustion (e.g., $\mathrm{NO}_{x}, \mathrm{HOA}$, and $\mathrm{BC}$ ) are similar and strong correlations between $\mathrm{SO}_{2}$ and $\mathrm{NO}_{x}$ are observed $\left(r=0.877\right.$, Fig. S17a). However, $\mathrm{SO}_{4}^{2-}$ exhibits a late morning peak during the day on both the weekdays and at weekends. A similar trend is seen for the other secondary inorganics as well as the secondary organics, although the morning increase is less distinct for LV-OOA.

\subsection{Insights into meteorological influences}

\subsubsection{Pollution events in Fresno during winter 2013}

Two main pollution events occurred during the campaign (14-23 January and 29 January-5 February), characterized by persistent exceedances of the NAAQS (Fig. 2e). The average $\mathrm{PM}_{1}$ concentration was higher during the first event than the second event $\left(44 \mu \mathrm{g} \mathrm{m}{ }^{-3}\right.$ compared to $36 \mu \mathrm{g} \mathrm{m}^{-3}$ ) (Fig. $2 \mathrm{~h}$ and $\mathrm{j}$ ) and the average compositions of $\mathrm{PM}_{1}$ are also fairly different. POA accounted for a greater proportion of the $\mathrm{PM}_{1}$ mass during the first event than the second event
(37\% vs. $29 \%$ ) (Fig. $2 \mathrm{i}$ and k), mainly due to the larger contribution of BBOA during the first event. The mass concentration of BBOA1, in particular, differs by a factor of 5 between the two events. Lower temperatures were experienced during the first event $\left(6.2^{\circ} \mathrm{C}\right.$ vs. $\left.9.5^{\circ} \mathrm{C}\right)$, which likely lead to an increase in biomass burning activities. However, both the RH and temperature were, on average, higher during the second event ( $63.8 \%$ vs. $68.9 \%)$, as well as the average concentration of ozone ( $6.2 \mathrm{ppb}$ vs. $9.5 \mathrm{ppb}$ ), which may have influenced the formation of secondary species through aqueous-phase processing and photochemistry. However, the difference in mass concentrations of SV-OOA and LV-OOA between the first and second events is not as large as that for BBOA1 suggesting that temperature has the largest influence on BBOA and thus the chemical composition during these two pollution events. Nevertheless, it is evident that meteorology influences both primary emissions and the production of secondary species during the campaign; although high $\mathrm{PM}_{1}$ concentrations are predominantly driven by primary species, the contributions from secondary species are still important (Fig. 9). 
Table 3. Comparison of aerosol properties and meteorological parameters between the campaign in Fresno in winter 2010 and winter 2013.

\begin{tabular}{lll}
\hline & $9-23$ Jan 2010 & 13 Jan-11 Feb 2013 \\
\hline $\begin{array}{l}\text { Average NR-PM } \\
\pm 1 \text { mass concentration }\end{array}$ & $11.7 \pm 10.8$ & $29.6 \pm 16.9$ \\
O $/ \mathrm{C}(\mathrm{H} / \mathrm{C})$ ratio* & & \\
OA factors from PMF & $0.35 \pm 0.07(1.75 \pm 0.08)$ & $0.42 \pm 0.10(1.70 \pm 0.05)$ \\
Temperature $\left({ }^{\circ} \mathrm{C}\right)($ average $\pm 1 \sigma)$ & HOA, COA, BBOA, OOA & HOA, COA, BBOA1, BBOA2, SV-OOA, LV-OOA \\
RH $(\%)$ (average $\pm 1 \sigma)$ & $8.7 \pm 3.1$ & $7.9 \pm 5.2$ \\
\hline
\end{tabular}

* calculated using the improved ambient method (Canagaratna et al., 2015).

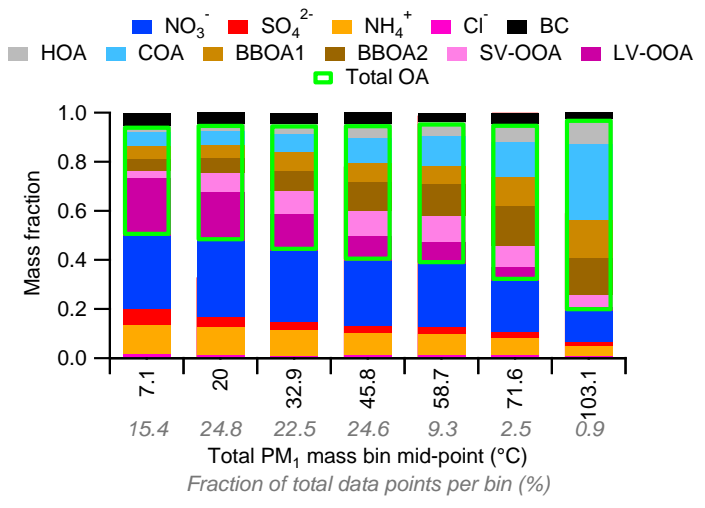

Figure 9. Mass fractional contribution to total $\mathrm{PM}_{1}$ of the nonrefractory secondary inorganic species (nitrate $\left(\mathrm{NO}_{3}^{-}\right)$, sulfate $\left(\mathrm{SO}_{4}^{2-}\right)$, ammonium $\left(\mathrm{NH}_{4}^{+}\right)$, chloride $\left(\mathrm{Cl}^{-}\right)$), black carbon $(\mathrm{BC})$, and the six OA factors (hydrocarbon-like OA (HOA), cooking OA (COA), biomass burning OA 1 (BBOA1), biomass burning OA 2 (BBOA2), semivolatile oxygenated OA (SV-OOA), low-volatility oxygenated OA (LV-OOA)) as a function of total $\mathrm{PM}_{1}$ mass during the whole campaign. The green outline indicates the fraction of total OA. Note that the final bin comprises the top four mass bins in order to improve the statistics for these high loading bins.

\subsubsection{Comparison with winter 2010}

In January 2010, similar measurements were made in Fresno at a site approximately $2.75 \mathrm{~km}$ from the one in this study (Ge et al., 2012a, b). Despite both campaigns taking place during wintertime and the close proximity of the two sites, there are notable differences between observed aerosol characteristics (Table 3). For example, the $\mathrm{PM}_{1}$ mass loading was much greater and approximately 2.5 times larger in 2013 than in $2010\left(31.0 \mathrm{\mu g} \mathrm{m}^{-3}\right.$ vs. $12.7 \mathrm{\mu g} \mathrm{m}^{-3}$, Fig. 10a). The average $\mathrm{O} / \mathrm{C}$ ratio of organics was also higher in $2013(0.42$ vs. 0.35 in 2010 ) and the $\mathrm{H} / \mathrm{C}$ was lower (1.70 vs. 1.75). One of the most noticeable differences between the two campaigns arises from the number and type of OA factors identified from PMF analysis of the organic aerosol fraction. In 2010, four OA factors were identified: HOA, COA, BBOA, and OOA, whereas in 2013 six factors were identified including two BBOA and two OOA factors, yet the type of emission

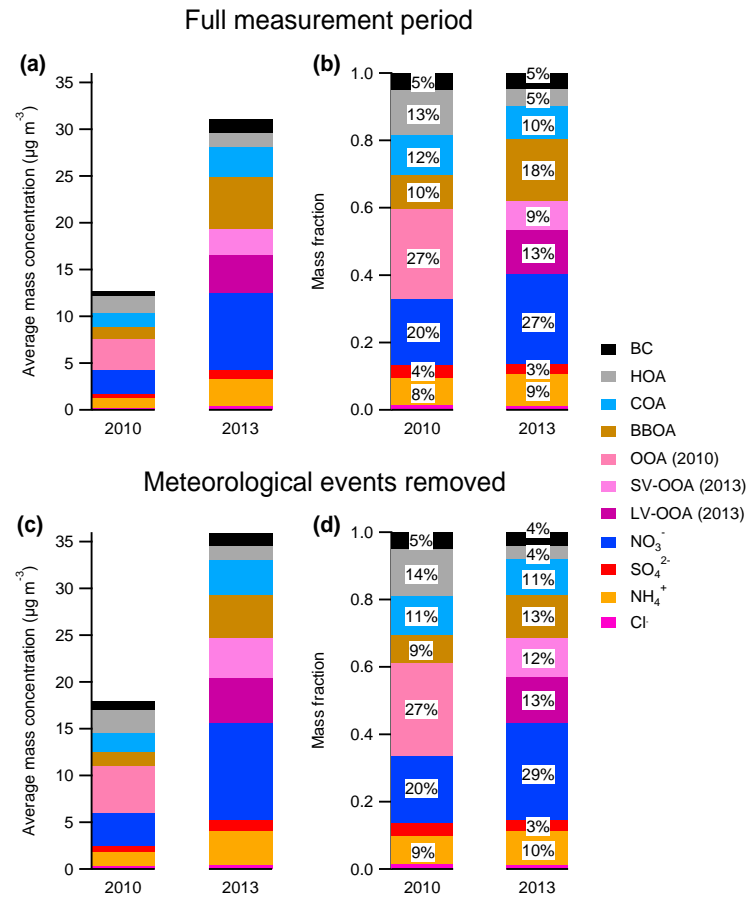

Figure 10. Comparison of aerosol composition between 2010 and 2013: (a) mass concentrations of all $\mathrm{PM}_{1}$ species for the full measurement period and (b) fractional contributions of $\mathrm{PM}_{1}$ species to the total $\mathrm{PM}_{1}$ mass for the full measurement period. (c) and (d) are the same as (a) and (b) except that the fog events and precipitation events are removed from the 2010 data set and the cold period and precipitation events are removed from the 2013 data set. In all cases, the organic fraction has been separated into its respective components determined from PMF analysis. BBOA1 and BBOA2 from 2013 have been summed to give the total BBOA mass and fractional contributions. $\mathrm{BC}$ in 2010 was estimated using the ratio of $\mathrm{BC}$ to POA in 2013. The contribution of chloride to total mass is $1 \%$ in all cases.

sources is not expected to have significantly changed within 3 years.

Meteorological conditions were noticeably different during the two measurement periods: on average, winter 2010, due to the influence of El Niño, had $16 \%$ higher RH and was $1.8^{\circ} \mathrm{C}$ warmer than winter 2013 (Fig. S18), with nearly 
$6{ }^{\circ} \mathrm{C}$ difference in the coldest temperatures $\left(4.0^{\circ} \mathrm{C}\right.$ in 2013 vs. $9.7^{\circ} \mathrm{C}$ in 2010 for the 25 th percentile). The average wind speed was much lower in $2013\left(1.0 \mathrm{~m} \mathrm{~s}^{-1}\right.$ compared to $5.7 \mathrm{~m} \mathrm{~s}^{-1}$ in 2010), and solar radiation was greater in 2013 and 2010 (average of 273 and $146 \mathrm{~W} \mathrm{~m}^{-2}$, respectively, for daylight hours, 06:00-17:00 PST). The higher total mass concentration in 2013 (Fig. 10a) can thus be attributed to the particularly stagnant conditions, which favor the accumulation of primary pollutants, from a more severe winter inversion with lower wind speeds and colder temperatures than those in 2010. In terms of fractional contributions of the species to the total mass, HOA and OOA are greater in 2010 than 2013 whereas nitrate and BBOA are greater in 2013 (Fig. 10b). In addition to winter 2013 being colder on average than winter 2010, especially low ambient temperatures during the first week (average of $5.5^{\circ} \mathrm{C}$ ) likely led to an increase in biomass burning in an effort to increase temperatures within the home during this period as discussed in Sect. 3.2.4. In comparison, it is likely that winter biomass burning activities are represented by only a single BBOA factor in 2010 due to the milder conditions and less dramatic temperature changes. In addition, since stagnant meteorological conditions tend to promote longer residence time of air pollutants and stronger solar radiation generally causes more intense photochemical processing of air pollutants, aerosol particles were likely overall more aged in 2013 than in 2010. The estimated size distributions of the OA factors, as well as nitrate and sulfate, were compared between 2013 and 2010 (Ge et al., 2012b); the particle sizes are observed to be narrower and larger in 2013 than in 2010 (Fig. S19). These differences appear to be consistent with overall more aged aerosol in 2013.

Ammonium nitrate is semivolatile with a strong dependency on temperature and humidity. Thus, for the following analyses all dense fog and precipitation events have been removed from the 2010 data, and the cold period and precipitation events have been removed from the 2013 data with the resulting mass concentrations and fractional contributions of $\mathrm{PM}_{1}$ species shown in Fig. 10c and d. There are several different nitrate production mechanisms including gas-to-particle partitioning, photochemical production of $\mathrm{HNO}_{3}$, as well as the mixing down of a nocturnal residual layer. In 2010, the diurnal cycle of nitrate (Fig. 11a) was attributed to enhanced gas-to-particle partitioning and nearsurface aqueous-phase processing from nighttime fogs (Ge et al., 2012a), where the nighttime fogs were not necessarily dense fogs. The diurnal profile of nitrate in 2013, however, is very different, with the highest average concentrations occurring during the late morning, suggesting that temporal variability in gas-to-particle partitioning due to surface-level fogs or instantaneous surface-level temperature is not a major pathway for nitrate production during winter 2013. This is further supported by the calculated diurnal profile of the ammonium nitrate equilibrium constant (see Sect. 2.3.4 for equations), which peaks in the early morning, approximately

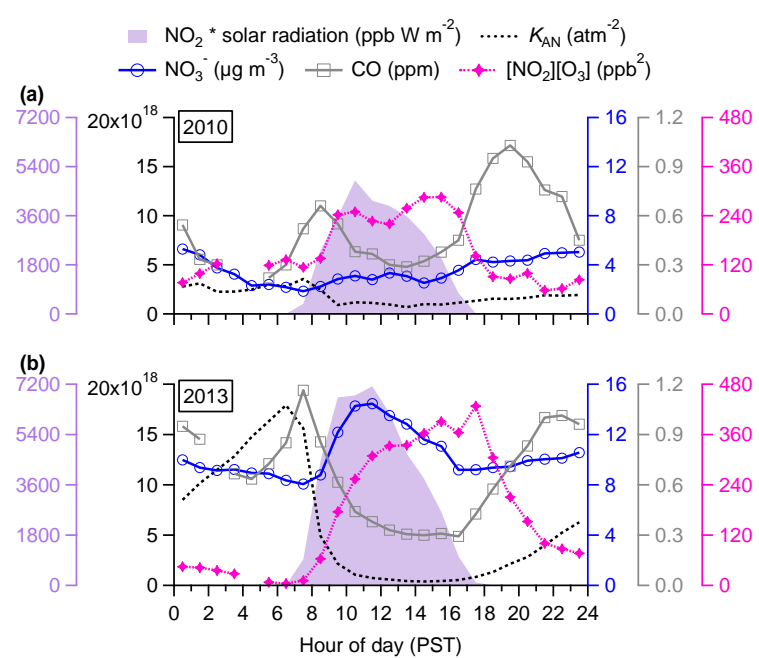

Figure 11. Diurnal profiles for nitrate and various parameters and proxies for formation pathways in 2010 (a) and 2013 (b). Parameters shown include temperature, $\mathrm{CO}$ for boundary layer dynamics, $\left[\mathrm{NO}_{2}\right]\left[\mathrm{O}_{3}\right]$ as a proxy for nighttime formation of $\mathrm{HNO}_{3}$ and subsequently particulate nitrate, $\left[\mathrm{NO}_{2}\right]$ times solar radiation as a proxy for daytime $\mathrm{HNO}_{3}$ formation and $K_{\mathrm{AN}}$ as the equilibrium constant for gas-to-particle partitioning for ammonium nitrate. As ammonium nitrate formation is dependent on temperature and humidity, fog events, cold periods, and precipitation events have been removed from the respective data sets prior to the analysis.

4-5 $\mathrm{h}$ before the peak in nitrate concentrations (Fig. 11b). It is estimated that on average, $\sim 90 \%$ of the total nitrate (the sum of particle-phase nitrate and the $\mathrm{HNO}_{3}$ for gas-phase nitrate) is in the particle phase, indicating that most $\mathrm{HNO}_{3}$ that formed has likely partitioned to the particle phase (Parworth et al., 2016). However, the measurements of $\mathrm{HNO}_{3}$ concentrations in 2013 are only approximately 7-hourly averages. Therefore, a proxy for the daytime photochemical $\mathrm{HNO}_{3}$ production rate, $\left[\mathrm{NO}_{2}\right]$ times solar radiation (e.g., Zhang et al., 2005b), is used here to better characterize any rapid changes in concentrations and thus likely daytime formation of nitrate. The proxy exhibits a similar peak in the diurnal pattern to that of nitrate suggesting photochemical production plays some role in the production of nitrate. However, the change in morning nitrate concentrations in 2013 is greater than 2010 and is larger than would be expected from the difference in the peak in the proxy between the 2 years. Consequently, photochemical production of nitrate likely only plays a small role in 2013 .

In a study conducted at Fresno between 2000 and 2005 (Chow et al., 2008), a peak in daily nitrate concentrations at 11:00-12:00 PST during winter was observed and attributed to the mixing down of a residual layer where particulate nitrate was formed aloft during the night and brought to the surface after sunrise following the breakup of the boundary layer (Watson and Chow, 2002a, b; Brown et al., 2006a; Chow et al., 2006). To investigate the influence of a resid- 
ual layer in enhancing nitrate concentrations at the surface in 2010 and 2013, the diurnal variations in CO (to represent changes in boundary layer dynamics) and in $\left[\mathrm{O}_{3}\right]\left[\mathrm{NO}_{2}\right]$ (a proxy for nighttime $\mathrm{HNO}_{3}$ production rate; see Sect. 2.3.5) are examined (Fig. 11). The CO profile is very similar in the evenings during the weekdays and weekend (Fig. 8), indicating that boundary layer dynamics are more important in influencing $\mathrm{CO}$ concentrations than rush hour emissions in the evening. At around 17:00 PST the sun sets, the boundary layer starts to collapse, and pollutants that mixed aloft during the day would be decoupled from the surface (Pusede et al., 2016). Consequently, the concentration of nitrate that could have formed during the night would depend on the initial concentrations of the pollutants such as $\mathrm{NO}_{2}$ and $\mathrm{O}_{3}$ in the residual layer. Overnight, $\mathrm{NO}_{2}$ and $\mathrm{O}_{3}$ react to form $\mathrm{N}_{2} \mathrm{O}_{5}$, which can react heterogeneously to form $\mathrm{HNO}_{3}$. As demonstrated in Sect. 2.3.5, under the assumption that $\mathrm{N}_{2} \mathrm{O}_{5}$ and $\mathrm{NO}_{3}$ are both in steady state (Brown et al., 2006b), the nighttime $\mathrm{HNO}_{3}$ production rate is proportional to $\left[\mathrm{NO}_{2}\right]\left[\mathrm{O}_{3}\right]$. Thus, the product of the $\mathrm{NO}_{2}$ and $\mathrm{O}_{3}$ concentrations at the point where the residual layer is formed (i.e., when the aloft atmosphere decouples from the surface) provides an approximation of $\mathrm{HNO}_{3}$ production in the nocturnal boundary layer. The concentration of $\mathrm{NO}_{2}$ at 17:00 PST was similar in 2010 as in 2013 ( 26 ppb vs. 20 ppb, on average) while the $\mathrm{O}_{3}$ concentration in 2010 at 17:00 PST was substantially smaller than in 2013 (5.5 ppb vs. $21 \mathrm{ppb}$ ). This indicates that $\mathrm{HNO}_{3}$ production from the $\mathrm{N}_{2} \mathrm{O}_{5}$ pathway was likely greater on average in 2013 than in 2010, which suggests the influence of the residual layer on daytime nitrate concentrations was more important in 2013. The influence of the residual layer in 2013 is evident on several days (Fig. S14c). In addition, it could be that the daytime losses of nitrate also differed between the 2 years. For example, the higher temperatures in 2010 may have resulted in a slightly greater fraction of $\mathrm{HNO}_{3}$ remaining in the gas phase.

The formation of other secondary species in 2010 was primarily attributed to in-fog processing and overall high humidity with enhanced gas-to-particle partitioning also playing an important role. However, in 2013 it is the nocturnal residual layer that appears to have the greatest influence on the diurnal variations of the secondary species; the diurnal profiles of the secondary inorganics, SV-OOA, and to some extent LV-OOA, are similar to that of nitrate, exhibiting the late morning peak in concentrations (Figs. 4 and 6). The influence of the residual layer is particularly clear when comparing the weekday and weekend diurnal profiles of sulfate and its precursor gas, $\mathrm{SO}_{2}$; the profiles are similar between weekdays and weekends for sulfate but not for $\mathrm{SO}_{2}$ (Fig. 8). In addition, a strong correlation is observed between $\mathrm{SO}_{2}$ and $\mathrm{CO}(r=0.871$, Fig. S17b). Although the nocturnal residual layer has previously been observed in Fresno (e.g., Watson and Chow, 2002b; Chow et al., 2006), its presence and subsequent influence on aerosol concentrations at the surface has typically been considered only in the context of nitrate. To our knowledge, this is the first time that the influence of the residual layer on other secondary species, such as sulfate and SOA, has been reported.

In contrast to 2010, two OOA subtypes, SV-OOA and LVOOA, were identified in 2013, which is surprising since more than one OOA factor is typically only observed at the same time during summer periods when the range in photochemical conditions and ambient temperature is larger (Jimenez et al., 2009). However, the solar radiation and the range of temperatures were larger in 2013 than 2010 (Fig. S18 and Table 3). Thus, it is possible that the contrast in meteorological conditions that influenced secondary aerosol formation in 2013 enabled OOA to be separated into the two subcomponents whereas the conditions were not as significantly different during the 2010 winter study. However, the fractional contribution of OOA to the total secondary aerosol mass is greater in 2010 than 2013 (Fig. 10b), which could be due in part to the large contribution from nitrate in 2013 as well as to aqueous-phase processing in fogs in 2010 (Ge et al., 2012b). The contribution of total OOA is similar between the 2 years when the dense fogs, precipitation events, and cold periods are removed from the respective data sets ( $27 \%$ vs. $25 \%)$, suggesting that aqueous-phase processing was more important for production of OOA in 2010 as the RH was higher on average throughout the 2010 campaign, whereas the greater solar radiation in 2013 led to more photochemical production of more oxidized OOA.

\section{Conclusions}

Particulate matter was characterized during winter 2013 at Fresno, one of the most populated cities in the SJV in California, using an HR-ToF-AMS as part of the NASA DISCOVER-AQ campaign. The average $\mathrm{PM}_{1}$ concentration was $31.0 \mu \mathrm{g} \mathrm{m}^{-3}$ and the total mass was dominated by organic aerosols $(55 \%)$, which had an average concentration of $17.1 \mu \mathrm{g} \mathrm{m}^{-3}$. OA had an average $\mathrm{O} / \mathrm{C}$ ratio of 0.42 and an $\mathrm{H} / \mathrm{C}$ ratio of 1.70 using the improved-ambient elemental analysis method recently reported in Canagaratna et al. (2015).

To gain insight into the sources and processes influencing the aerosols in Fresno, PMF was applied to the OA fraction where six factors were identified: HOA associated with local traffic, COA associated with food cooking activities, two BBOAs (BBOA1 and BBOA2) associated with residential space heating from wood combustion, and SV-OOA and LVOOA formed via chemical reactions in the atmosphere. During winter 2013, the four POA factors (HOA, COA, BBOA1, and BBOA2) accounted for $60 \%$ of the total OA mass with the other $40 \%$ accounted for by the two secondary OA factors. LV-OOA represented the largest OA component (24\%) and accounts for $60 \%$ of the total SOA mass.

The two BBOAs differed temporally and chemically, where BBOA1 was markedly present during the first few 
days of the campaign and had a less distinct diurnal profile compared to BBOA2. BBOA2 was observed to be more oxygenated than BBOA1 and correlated better with most biomass burning tracers other than the nitrogen-containing species with which BBOA1 had a stronger relationship. Differences in the two factors were likely due predominantly to burning behaviors and variations in meteorology whereby temperatures during the first week of the campaign were below freezing, leading to an increase in residential wood combustion for space heating.

Similar measurements were performed at a nearby location during winter in 2010 yet the resulting aerosol chemistry is considerably different to that of 2013, where the average NR-PM 1 concentration in 2013 was more than a factor of 2 greater than $2010\left(29.6 \mu \mathrm{g} \mathrm{m}^{-3}\right.$ compared to $\left.11.7 \mu \mathrm{g} \mathrm{m}^{-3}\right)$. In 2013 the contribution of nitrate to the total $\mathrm{PM}_{1}\left(\mathrm{NR}-\mathrm{PM}_{1}\right.$ plus BC) was greater than in 2010 and another BBOA and OOA factor were identified in addition to the HOA, COA, BBOA, and OOA factors derived from the 2010 OA data set. As the types of aerosol sources are unlikely to have changed significantly between 2010 and 2013, observed differences are predominantly due to meteorological influences, with colder and drier conditions in 2013 than 2010. Coupled with low wind speeds, the stagnant conditions in 2013 favored the accumulation of pollution. In addition, the first week of the 2013 campaign was characterized by a period of particularly low temperatures, likely resulting in an increase in biomass burning activities and thus the identification of two BBOA factors in 2013. However, gas-to-particle partitioning due to lower temperatures could not fully explain the observed increase in nitrate concentrations from 2010 to 2013. The excess nitrate mass was attributed to photochemical formation during the day as well as the addition of nitrate in the late morning which had formed in a residual layer aloft during the night. The nocturnal residual layer is also observed to influence the diurnal variation in concentrations of other secondary inorganic and organic aerosols. The greater solar radiation and larger range in temperature likely lead to both SV-OOA and LV-OOA being observed in 2013, whereas the meteorological conditions were not as contrasting in 2010 and OOA production was influenced more by aqueous-phase processes, particularly in fogs.

\section{Data availability}

Processed data from the DISCOVER-AQ project are available to the public at http://www-air.larc.nasa.gov/missions/ discover-aq/discover-aq.html.

The hourly ambient temperature and $\mathrm{RH}$ data as well as trace gas data (e.g., $\mathrm{CO}$ and $\mathrm{NO}_{2}$ concentrations) were acquired from the CARB website (http://www.arb.ca.gov/html/ ds.htm).

Raw data are archived at the University of California, Davis, and are available on request.

\section{The Supplement related to this article is available online at doi:10.5194/acp-16-5427-2016-supplement.}

Acknowledgements. This research was supported by NASA, the California Agricultural Experiment Station (project CA-D-ETX2102-H), DOE (grant no. DE-FG02-11ER65293, DE-SC0007178), and the California Air Resources Board (14-307). Caroline Parworth also acknowledges the National Science Foundation (NSF) Graduate Research Fellowship under grant no. DGE1148897. Roger Seco was partly supported by a postdoctoral fellowship awarded by Fundación Ramón Areces. The authors thank James Crawford (NASA) for organizing and directing the DISCOVER-AQ campaign and the California Air Resources Board (CARB) measurement facility located in Fresno for providing meteorological and trace-gas data. Special thanks to Patrick Seames (CARB) for all of his help and generosity at the CARB site and Sonya Collier, Xinlei Ge, and Jianzhong Xu (UCD) for helping during the field study. This manuscript has not been reviewed by the funding agencies and no endorsement should be inferred.

Edited by: S. Brown

\section{References}

Aiken, A. C., Decarlo, P. F., Kroll, J. H., Worsnop, D. R., Huffman, J. A., Docherty, K. S., Ulbrich, I. M., Mohr, C., Kimmel, J. R., Sueper, D., Sun, Y., Zhang, Q., Trimborn, A., Northway, M., Ziemann, P. J., Canagaratna, M. R., Onasch, T. B., Alfarra, M. R., Prévôt, A. S. H., Dommen, J., Duplissy, J., Metzger, A., Baltensperger, U., and Jimenez, J. L.: O / C and OM / OC ratios of primary, secondary, and ambient organic aerosols with high-resolution time-of-flight aerosol mass spectrometry, Environ. Sci. Technol., 42, 4478-4485, 2008.

Aiken, A. C., Salcedo, D., Cubison, M. J., Huffman, J. A., DeCarlo, P. F., Ulbrich, I. M., Docherty, K. S., Sueper, D., Kimmel, J. R., Worsnop, D. R., Trimborn, A., Northway, M., Stone, E. A., Schauer, J. J., Volkamer, R. M., Fortner, E., de Foy, B., Wang, J., Laskin, A., Shutthanandan, V., Zheng, J., Zhang, R., Gaffney, J., Marley, N. A., Paredes-Miranda, G., Arnott, W. P., Molina, L. T., Sosa, G., and Jimenez, J. L.: Mexico City aerosol analysis during MILAGRO using high resolution aerosol mass spectrometry at the urban supersite (T0) - Part 1: Fine particle composition and organic source apportionment, Atmos. Chem. Phys., 9, 6633-6653, doi:10.5194/acp-9-6633-2009, 2009.

Alfarra, M. R., Coe, H., Allan, J. D., Bower, K. N., Boudries, H., Canagaratna, M. R., Jimenez, J. L., Jayne, J. T., Garforth, A. A., Li, S.-M., and Worsnop, D. R.: Characterization of urban and rural organic particulate in the Lower Fraser Valley using two Aerodyne Aerosol Mass Spectrometers, Atmos. Environ., 38, 5745-5758, 2004.

Alfarra, M. R., Prevot, A. S. H., Szidat, S., Sandradewi, J., Weimer, S., Lanz, V. A., Schreiber, D., Mohr, M., and Baltensperger, U.: Identification of the Mass Spectral Signature of Organic Aerosols from Wood Burning Emissions, Environ. Sci. Technol., 41, 5770-5777, 2007. 
Allan, J. D., Delia, A. E., Coe, H., Bower, K. N., Alfarra, M. R., Jimenez, J. L., Middlebrook, A. M., Drewnick, F., Onasch, T. B., Canagaratna, M. R., Jayne, J. T., and Worsnop, D. R.: A generalised method for the extraction of chemically resolved mass spectra from aerodyne aerosol mass spectrometer data, J. Aerosol Sci., 35, 909-922, 2004.

Allan, J. D., Williams, P. I., Morgan, W. T., Martin, C. L., Flynn, M. J., Lee, J., Nemitz, E., Phillips, G. J., Gallagher, M. W., and Coe, H.: Contributions from transport, solid fuel burning and cooking to primary organic aerosols in two UK cities, Atmos. Chem. Phys., 10, 647-668, doi:10.5194/acp-10-647-2010, 2010.

American Lung Association, State of the air: 2016 report, available at: http://www.lung.org/our-initiatives/healthy-air/sota/, last access: 26 April 2016.

Borbon, A., Fontaine, H., Veillerot, M., Locoge, N., Galloo, J. C., and Guillermo, R.: An investigation into the traffic-related fraction of isoprene at an urban location, Atmos. Environ., 35, 37493760, 2001.

Brito, J., Rizzo, L. V., Morgan, W. T., Coe, H., Johnson, B., Haywood, J., Longo, K., Freitas, S., Andreae, M. O., and Artaxo, P.: Ground-based aerosol characterization during the South American Biomass Burning Analysis (SAMBBA) field experiment, Atmos. Chem. Phys., 14, 12069-12083, doi:10.5194/acp-1412069-2014, 2014

Brown, S. G., Roberts, P. T., McCarthy, M. C., Lurmann, F. W., and Hyslop, N. P.: Wintertime vertical variations in particulate matter (PM) and precursor concentrations in the San Joaquin Valley during the California Regional coarse PM/fine PM Air Quality Study, J. Air Waste Manage., 56, 1267-1277, 2006a.

Brown, S. S., Ryerson, T. B., Wollny, A. G., Brock, C. A., Peltier, R., Sullivan, A. P., Weber, R. J., Dubé, W. P., Trainer, M., Meagher, J. F., Fehsenfeld, F. C., and Ravishankara, A. R.: Variability in Nocturnal Nitrogen Oxide Processing and Its Role in Regional Air Quality, Science, 311, 67-70, 2006b.

Canagaratna, M. R., Jayne, J. T., Ghertner, D. A., Herndon, S., Shi, Q., Jimenez, J. L., Silva, P. J., Williams, P., Lanni, T., Drewnick, F., Demerjian, K. L., Kolb, C. E., and Worsnop, D. R.: Chase studies of particulate emissions from in-use New York City vehicles, Aerosol Sci. Tech., 38, 555-573, 2004.

Canagaratna, M. R., Jayne, J. T., Jimenez, J. L., Allan, J. D., Alfarra, M. R., Zhang, Q., Onasch, T. B., Drewnick, F., Coe, H., Middlebrook, A., Delia, A., Williams, L. R., Trimborn, A. M., Northway, M. J., DeCarlo, P. F., Kolb, C. E., Davidovits, P., and Worsnop, D. R.: Chemical and microphysical characterization of ambient aerosols with the aerodyne aerosol mass spectrometer, Mass Spectrom. Rev., 26, 185-222, 2007.

Canagaratna, M. R., Jimenez, J. L., Kroll, J. H., Chen, Q., Kessler, S. H., Massoli, P., Hildebrandt Ruiz, L., Fortner, E., Williams, L. R., Wilson, K. R., Surratt, J. D., Donahue, N. M., Jayne, J. T., and Worsnop, D. R.: Elemental ratio measurements of organic compounds using aerosol mass spectrometry: characterization, improved calibration, and implications, Atmos. Chem. Phys., 15, 253-272, doi:10.5194/acp-15-253-2015, 2015.

CARB: California Air Resources Board, Air Quality and Emissions, available at: http://www.arb.ca.gov/html/ds.htm, 2013.

Carslaw, D.: The openair manual - open-source tools for analysing air pollution data, Manual for version 1.1-4, King's College London, 2015
Carslaw, D. C. and Ropkins, K.: openair - An R package for air quality data analysis, Environ. Modell. Softw., 27-28, 52-61, 2012.

Chen, L. W. A., Watson, J. G., Chow, J. C., and Magliano, K. L.: Quantifying PM2.5 source contributions for the San Joaquin Valley with multivariate receptor models, Environ. Sci. Technol., 41, 2818-2826, 2007.

Chow, J. C., Chen, L. W. A., Watson, J. G., Lowenthal, D. H., Magliano, K. A., Turkiewicz, K., and Lehrman, D. E.: $\mathrm{PM}_{2.5}$ chemical composition and spatiotemporal variability during the California Regional $\mathrm{PM}_{10} / \mathrm{PM}_{2.5}$ Air Quality Study (CRPAQS), J. Geophys. Res.-Atmos., 111, D10S04, doi:10.1029/2005JD006457, 2006.

Chow, J. C., Watson, J. G., Lowenthal, D. H., Park, K., Doraiswamy, P., Bowers, K., and Bode, R.: Continuous and filter-based measurements of $\mathrm{PM}_{2.5}$ nitrate and sulfate at the Fresno Supersite, Environ. Monit. Assess., 144, 179-189, 2008.

Chow, J. C., Watson, J. G., Lowenthal, D. H., Solomon, P. A., Magliano, K. L., Ziman, S. D., and Richards, L. W.: Pm(10) and Pm(2.5) Compositions in California San Joaquin Valley, Aerosol Sci. Tech., 18, 105-128, 1993.

Chu, S. H., Paisie, J. W., and Jang, B. W. L.: PM data analysis a comparison of two urban areas: Fresno and Atlanta, Atmos. Environ., 38, 3155-3164, 2004.

Collett, J. L., Hoag, K. J., Sherman, D. E., Bator, A., and Richards, L. W.: Spatial and temporal variations in San Joaquin Valley fog chemistry, Atmos. Environ., 33, 129-140, 1999.

Collier, S. and Zhang, Q.: Gas-Phase $\mathrm{CO}_{2}$ Subtraction for Improved Measurements of the Organic Aerosol Mass Concentration and Oxidation Degree by an Aerosol Mass Spectrometer, Environ. Sci. Technol., 47, 14324-14331, 2013.

Collier, S., Zhou, S., Kuwayama, T., Forestieri, S., Brady, J., Zhang, M., Kleeman, M., Cappa, C., Bertram, T., and Zhang, Q.: Organic PM Emissions from Vehicles: Composition, O / C Ratio, and Dependence on PM Concentration, Aerosol Sci. Tech., 49, 86-97, 2015.

Crippa, M., DeCarlo, P. F., Slowik, J. G., Mohr, C., Heringa, M. F., Chirico, R., Poulain, L., Freutel, F., Sciare, J., Cozic, J., Di Marco, C. F., Elsasser, M., Nicolas, J. B., Marchand, N., Abidi, E., Wiedensohler, A., Drewnick, F., Schneider, J., Borrmann, S., Nemitz, E., Zimmermann, R., Jaffrezo, J.-L., Prévôt, A. S. H., and Baltensperger, U.: Wintertime aerosol chemical composition and source apportionment of the organic fraction in the metropolitan area of Paris, Atmos. Chem. Phys., 13, 961-981, doi:10.5194/acp-13-961-2013, 2013.

Cubison, M. J., Ortega, A. M., Hayes, P. L., Farmer, D. K., Day, D., Lechner, M. J., Brune, W. H., Apel, E., Diskin, G. S., Fisher, J. A., Fuelberg, H. E., Hecobian, A., Knapp, D. J., Mikoviny, T., Riemer, D., Sachse, G. W., Sessions, W., Weber, R. J., Weinheimer, A. J., Wisthaler, A., and Jimenez, J. L.: Effects of aging on organic aerosol from open biomass burning smoke in aircraft and laboratory studies, Atmos. Chem. Phys., 11, 12049-12064, doi:10.5194/acp-11-12049-2011, 2011.

Dall'Osto, M., Harrison, R. M., Coe, H., and Williams, P.: Real-time secondary aerosol formation during a fog event in London, Atmos. Chem. Phys., 9, 2459-2469, doi:10.5194/acp-9-2459-2009, 2009.

DeCarlo, P. F., Kimmel, J. R., Trimborn, A., Northway, M. J., Jayne, J. T., Aiken, A. C., Gonin, M., Fuhrer, K., Horvath, T., Docherty, 
K. S., Worsnop, D. R., and Jimenez, J. L.: Field-Deployable, High-Resolution, Time-of-Flight Aerosol Mass Spectrometer, Anal Chem, 78, 8281-8289, 2006.

DeCarlo, P. F., Ulbrich, I. M., Crounse, J., de Foy, B., Dunlea, E. J., Aiken, A. C., Knapp, D., Weinheimer, A. J., Campos, T., Wennberg, P. O., and Jimenez, J. L.: Investigation of the sources and processing of organic aerosol over the Central Mexican Plateau from aircraft measurements during MILAGRO, Atmos. Chem. Phys., 10, 5257-5280, doi:10.5194/acp-10-52572010, 2010.

Drewnick, F., Jayne, J. T., Canagaratna, M., Worsnop, D. R., and Demerjian, K. L.: Measurement of Ambient Aerosol Composition During the PMTACS-NY 2001 Using an Aerosol Mass Spectrometer. Part II: Chemically Speciated Mass Distributions Special Issue of Aerosol Sci. Tech. on Findings from the Fine Particulate Matter Supersites Program, Aerosol Sci. Tech., 38, 104-117, 2004.

Dzepina, K., Arey, J., Marr, L. C., Worsnop, D. R., Salcedo, D., Zhang, Q., Onasch, T. B., Molina, L. T., Molina, M. J., and Jimenez, J. L.: Detection of particle-phase polycyclic aromatic hydrocarbons in Mexico City using an aerosol mass spectrometer, Int. J. Mass Spectrom., 263, 152-170, 2007.

Ervens, B., Turpin, B. J., and Weber, R. J.: Secondary organic aerosol formation in cloud droplets and aqueous particles (aqSOA): a review of laboratory, field and model studies, Atmos. Chem. Phys., 11, 11069-11102, doi:10.5194/acp-1111069-2011, 2011.

Ge, X., Setyan, A., Sun, Y., and Zhang, Q.: Primary and secondary organic aerosols in Fresno, California during wintertime: Results from high resolution aerosol mass spectrometry, J. Geophys. Res.-Atmos., 117, D19301, doi:10.1029/2012JD018026, 2012a.

Ge, X., Zhang, Q., Sun, Y., Ruehl, C. R., and Setyan, A.: Effect of aqueous-phase processing on aerosol chemistry and size distributions in Fresno, California, during wintertime, Environ. Chem., 9, 221-235, doi:10.1071/EN11168, 2012b.

Gelencsér, A., May, B., Simpson, D., Sánchez-Ochoa, A., KasperGiebl, A., Puxbaum, H., Caseiro, A., Pio, C., and Legrand, M.: Source apportionment of $\mathrm{PM}_{2} .5$ organic aerosol over Europe: Primary/secondary, natural/anthropogenic, and fossil/biogenic origin, 112, D23S04, doi:10.1029/2006JD008094, 2007.

Goldstein, A. H., Koven, C. D., Heald, C. L., and Fung, I. Y.: Biogenic carbon and anthropogenic pollutants combine to form a cooling haze over the southeastern United States, P. Natl. Acad. Sci., 106, 8835-8840, 2009.

Gorin, C. A., Collett, J. L., and Herckes, P.: Wood Smoke Contribution to Winter Aerosol in Fresno, CA, J. Air Waste Manage., 56, 1584-1590, 2006.

Graus, M., Müller, M., and Hansel, A.: High Resolution PTR-TOF: Quantification and Formula Confirmation of VOC in Real Time, J. Am. Soc. Mass Spectr., 21, 1037-1044, 2010.

Hall, J. V., Braker, V., and Lurmann, F. W.: The benefits of meeting federal clean air standards in the South Coast and San Joaquin Valley air basins, California State University, 2008.

Hannigan, M. P., Cass, G. R., Penman, B. W., Crespi, C. L., Lafleur, A. L., Busby, W. F., Thilly, W. G., and Simoneit, B. R. T.: Bioassay-Directed Chemical Analysis of Los Angeles Airborne Particulate Matter Using a Human Cell Mutagenicity Assay, Environ. Sci. Technol., 32, 3502-3514, 1998.
Harrison, R. M. and Yin, J.: Particulate matter in the atmosphere: which particle properties are important for its effects on health?, Sci. Total Environ., 249, 85-101, 2000.

Herckes, P., Leenheer, J. A., and Collett, J. L.: Comprehensive Characterization of Atmospheric Organic Matter in Fresno, California Fog Water, Environ. Sci. Technol., 41, 393-399, 2007.

Heringa, M. F., DeCarlo, P. F., Chirico, R., Tritscher, T., Dommen, J., Weingartner, E., Richter, R., Wehrle, G., Prévôt, A. S. H., and Baltensperger, U.: Investigations of primary and secondary particulate matter of different wood combustion appliances with a high-resolution time-of-flight aerosol mass spectrometer, Atmos. Chem. Phys., 11, 5945-5957, doi:10.5194/acp-11-59452011, 2011.

Herndon, S. C., Onasch, T. B., Wood, E. C., Kroll, J. H., Canagaratna, M. R., Jayne, J. T., Zavala, M. A., Knighton, W. B., Mazzoleni, C., Dubey, M. K., Ulbrich, I. M., Jimenez, J. L., Seila, R., de Gouw, J. A., de Foy, B., Fast, J., Molina, L. T., Kolb, C. E., and Worsnop, D. R.: Correlation of secondary organic aerosol with odd oxygen in Mexico City, Geophys. Res. Lett., 35, L15804, doi:10.1029/2008GL034058, 2008.

IPCC: Summary for policymakers, in: Climate Change 2013: The Physical Science Basis. Contribution of Working Group 1 to the Fifth Assessment Report of the Intergovernmental Panel on Climate Change, edited by: Stocker, T. F., Qin, D., Plattner, G.-K., Tignor, M., Allen, S. K., Boschung, J., Nauels, A., Xia, Y., Bex, V., and Midgley, P. M., Cambridge University Press, Cambridge, UK, New York, NY, USA, 2013.

Jimenez, J. L., Canagaratna, M. R., Donahue, N. M., Prevot, A. S. H., Zhang, Q., Kroll, J. H., DeCarlo, P. F., Allan, J. D., Coe, H., Ng, N. L., Aiken, A. C., Docherty, K. S., Ulbrich, I. M., Grieshop, A. P., Robinson, A. L., Duplissy, J., Smith, J. D., Wilson, K. R., Lanz, V. A., Hueglin, C., Sun, Y. L., Tian, J., Laaksonen, A., Raatikainen, T., Rautiainen, J., Vaattovaara, P., Ehn, M., Kulmala, M., Tomlinson, J. M., Collins, D. R., Cubison, M. J., E., Dunlea, J., Huffman, J. A., Onasch, T. B., Alfarra, M. R., Williams, P. I., Bower, K., Kondo, Y., Schneider, J., Drewnick, F., Borrmann, S., Weimer, S., Demerjian, K., Salcedo, D., Cottrell, L., Griffin, R., Takami, A., Miyoshi, T., Hatakeyama, S., Shimono, A., Sun, J. Y., Zhang, Y. M., Dzepina, K., Kimmel, J. R., Sueper, D., Jayne, J. T., Herndon, S. C., Trimborn, A. M., Williams, L. R., Wood, E. C., Middlebrook, A. M., Kolb, C. E., Baltensperger, U., and Worsnop, D. R.: Evolution of Organic Aerosols in the Atmosphere, Science, 326, 1525-1529, 2009.

Jordan, T. B., Seen, A. J., and Jacobsen, G. E.: Levoglucosan as an atmospheric tracer for woodsmoke, Atmos. Environ., 40, 53165321, 2006.

Kanakidou, M., Seinfeld, J. H., Pandis, S. N., Barnes, I., Dentener, F. J., Facchini, M. C., Van Dingenen, R., Ervens, B., Nenes, A., Nielsen, C. J., Swietlicki, E., Putaud, J. P., Balkanski, Y., Fuzzi, S., Horth, J., Moortgat, G. K., Winterhalter, R., Myhre, C. E. L., Tsigaridis, K., Vignati, E., Stephanou, E. G., and Wilson, J.: Organic aerosol and global climate modelling: a review, Atmos. Chem. Phys., 5, 1053-1123, doi:10.5194/acp-5-1053-2005, 2005.

Lanz, V. A., Alfarra, M. R., Baltensperger, U., Buchmann, B., Hueglin, C., and Prévôt, A. S. H.: Source apportionment of submicron organic aerosols at an urban site by factor analytical modelling of aerosol mass spectra, Atmos. Chem. Phys., 7, 15031522, doi:10.5194/acp-7-1503-2007, 2007. 
Lanz, V. A., Alfarra, M. R., Baltensperger, U., Buchmann, B., Hueglin, C., Szidat, S., Wehrli, M. N., Wacker, L., Weimer, S., Caseiro, A., Puxbaum, H., and Prevot, A. S. H.: Source Attribution of Submicron Organic Aerosols during Wintertime Inversions by Advanced Factor Analysis of Aerosol Mass Spectra, Environ. Sci. Technol., 42, 214-220, 2008.

Lurmann, F. W., Brown, S. G., McCarthy, M. C., and Roberts, P. T.: Processes influencing secondary aerosol formation in the San Joaquin Valley during winter, J. Air Waste Manage., 56, 1679_ 1693, 2006.

Marr, L. C., Dzepina, K., Jimenez, J. L., Reisen, F., Bethel, H. L., Arey, J., Gaffney, J. S., Marley, N. A., Molina, L. T., and Molina, M. J.: Sources and transformations of particle-bound polycyclic aromatic hydrocarbons in Mexico City, Atmos. Chem. Phys., 6, 1733-1745, doi:10.5194/acp-6-1733-2006, 2006.

Martin, C. L., Allan, J. D., Crosier, J., Choularton, T. W., Coe, H., and Gallagher, M. W.: Seasonal variation of fine particulate composition in the centre of a UK city, Atmos. Environ., 45, 43794389, 2011.

Middlebrook, A. M., Bahreini, R., Jimenez, J. L., and Canagaratna, M. R.: Evaluation of Composition-Dependent Collection Efficiencies for the Aerodyne Aerosol Mass Spectrometer using Field Data, Aerosol Sci. Tech., 46, 258-271, 2012.

Mohr, C., DeCarlo, P. F., Heringa, M. F., Chirico, R., Slowik, J. G., Richter, R., Reche, C., Alastuey, A., Querol, X., Seco, R., Peñuelas, J., Jiménez, J. L., Crippa, M., Zimmermann, R., Baltensperger, U., and Prévôt, A. S. H.: Identification and quantification of organic aerosol from cooking and other sources in Barcelona using aerosol mass spectrometer data, Atmos. Chem. Phys., 12, 1649-1665, doi:10.5194/acp-12-1649-2012, 2012.

Morgan, W. T., Allan, J. D., Bower, K. N., Highwood, E. J., Liu, D., McMeeking, G. R., Northway, M. J., Williams, P. I., Krejci, R., and Coe, H.: Airborne measurements of the spatial distribution of aerosol chemical composition across Europe and evolution of the organic fraction, Atmos. Chem. Phys., 10, 4065-4083, doi:10.5194/acp-10-4065-2010, 2010.

Müller, M., Mikoviny, T., Jud, W., D’Anna, B., and Wisthaler, A.: A new software tool for the analysis of high resolution PTR-TOF mass spectra, Chemometr. Intell. Lab., 127, 158-165, 2013.

NASA DISCOVER-AQ project data: available at: http://www-air. larc.nasa.gov/missions/discover-aq/discover-aq.html, 2013.

Ng, N. L., Canagaratna, M. R., Zhang, Q., Jimenez, J. L., Tian, J., Ulbrich, I. M., Kroll, J. H., Docherty, K. S., Chhabra, P. S., Bahreini, R., Murphy, S. M., Seinfeld, J. H., Hildebrandt, L., Donahue, N. M., DeCarlo, P. F., Lanz, V. A., Prévôt, A. S. H., Dinar, E., Rudich, Y., and Worsnop, D. R.: Organic aerosol components observed in Northern Hemispheric datasets from Aerosol Mass Spectrometry, Atmos. Chem. Phys., 10, 46254641, doi:10.5194/acp-10-4625-2010, 2010.

Ngo, M. A., Pinkerton, K. E., Freeland, S., Geller, M., Ham, W., Cliff, S., Hopkins, L. E., Kleeman, M. J., Kodavanti, U. P., Meharg, E., Plummer, L., Recendez, J. J., Schenker, M. B., Sioutas, C., Smiley-Jewell, S., Haas, C., Gutstein, J., and Wexler, A. S.: Airborne particles in the San Joaquin Valley may affect human health, California Agriculture, 64, 12-16, 2010.

Ortega, A. M., Day, D. A., Cubison, M. J., Brune, W. H., Bon, D., de Gouw, J. A., and Jimenez, J. L.: Secondary organic aerosol formation and primary organic aerosol oxidation from biomass-burning smoke in a flow reactor during FLAME-3,
Atmos. Chem. Phys., 13, 11551-11571, doi:10.5194/acp-1311551-2013, 2013.

Otto, A., Gondokusumo, R., and Simpson, M. J.: Characterization and quantification of biomarkers from biomass burning at a recent wildfire site in Northern Alberta, Canada, Appl. Geochem., 21, 166-183, 2006.

Paatero, P. and Tapper, U.: Positive matrix factorization: A nonnegative factor model with optimal utilization of error estimates of data values, Environmetrics, 5, 111-126, 1994.

Paatero, P., Hopke, P. K., Song, X.-H., and Ramadan, Z.: Understanding and controlling rotations in factor analytic models, Chemometr. Intell. Lab., 60, 253-264, 2002.

Parworth, C., Fast, J., Mei, F., Shippert, T., Sivaraman, C., Tilp, A., Watson, T., and Zhang, Q.: Long-term measurements of submicrometer aerosol chemistry at the Southern Great Plains (SGP) using an Aerosol Chemical Speciation Monitor (ACSM), Atmos. Environ., 106, 43-55, 2015.

Parworth, C. L., Young, D. E., Kim, H., Collier, S., Zhang, X., Cappa, C. D., and Zhang, Q.: Wintertime water-soluble PM2.5 composition and particle water content in Fresno: Results from DISCOVER-AQ California, in preparation, 2016.

Phinney, L., Richard Leaitch, W., Lohmann, U., Boudries, H., Worsnop, D. R., Jayne, J. T., Toom-Sauntry, D., Wadleigh, M., Sharma, S., and Shantz, N.: Characterization of the aerosol over the sub-arctic north east Pacific Ocean, Deep Sea Research Part II: Topical Studies in Oceanography, 53, 2410-2433, 2006.

Pope, C. A. and Dockery, D. W.: Health Effects of Fine Particulate Air Pollution: Lines that Connect, J. Air Waste Manage., 56, 709-742, 2006.

Pöschl, U.: Atmospheric Aerosols: Composition, Transformation, Climate and Health Effects, Angew. Chem. Int. Ed. , 44, 7520 7540, 2005.

Pusede, S. E., Duffey, K. C., Shusterman, A. A., Saleh, A., Laughner, J. L., Wooldridge, P. J., Zhang, Q., Parworth, C. L., Kim, H., Capps, S. L., Valin, L. C., Cappa, C. D., Fried, A., Walega, J., Nowak, J. B., Weinheimer, A. J., Hoff, R. M., Berkoff, T. A., Beyersdorf, A. J., Olson, J., Crawford, J. H., and Cohen, R. C.: On the effectiveness of nitrogen oxide reductions as a control over ammonium nitrate aerosol, Atmos. Chem. Phys., 16, 25752596, doi:10.5194/acp-16-2575-2016, 2016.

Schneider, J., Weimer, S., Drewnick, F., Borrmann, S., Helas, G., Gwaze, P., Schmid, O., Andreae, M. O., and Kirchner, U.: Mass spectrometric analysis and aerodynamic properties of various types of combustion-related aerosol particles, Int. J. Mass Spectrom., 258, 37-49, 2006.

Schwarz, J. P., Gao, R. S., Fahey, D. W., Thomson, D. S., Watts, L. A., Wilson, J. C., Reeves, J. M., Darbeheshti, M., Baumgardner, D. G., Kok, G. L., Chung, S. H., Schulz, M., Hendricks, J., Lauer, A., Kärcher, B., Slowik, J. G., Rosenlof, K. H., Thompson, T. L., Langford, A. O., Loewenstein, M., and Aikin, K. C.: Single-particle measurements of midlatitude black carbon and light-scattering aerosols from the boundary layer to the lower stratosphere, J. Geophys. Res.-Atmos., 111, D16207, doi:10.1029/2006JD007076, 2006.

Seco, R., Peñuelas, J., Filella, I., Llusia, J., Schallhart, S., Metzger, A., Müller, M., and Hansel, A.: Volatile organic compounds in the western Mediterranean basin: urban and rural winter measurements during the DAURE campaign, Atmos. Chem. Phys., 13, 4291-4306, doi:10.5194/acp-13-4291-2013, 2013. 
Seinfeld, J. H. and Pandis, S. N.: Atmospheric Chemistry and Physics: From Air Pollution to Climate Change, John Wiley \& Sons, New York, 2nd edition, 1232 pp., ISBN-13: 978-0-47172018-8, 2006.

Setyan, A., Zhang, Q., Merkel, M., Knighton, W. B., Sun, Y., Song, C., Shilling, J. E., Onasch, T. B., Herndon, S. C., Worsnop, D. R., Fast, J. D., Zaveri, R. A., Berg, L. K., Wiedensohler, A., Flowers, B. A., Dubey, M. K., and Subramanian, R.: Characterization of submicron particles influenced by mixed biogenic and anthropogenic emissions using high-resolution aerosol mass spectrometry: results from CARES, Atmos. Chem. Phys., 12, 8131-8156, doi:10.5194/acp-12-8131-2012, 2012.

Simoneit, B. R. T., Schauer, J. J., Nolte, C. G., Oros, D. R., Elias, V. O., Fraser, M. P., Rogge, W. F., and Cass, G. R.: Levoglucosan, a tracer for cellulose in biomass burning and atmospheric particles, Atmos. Environ., 33, 173-182, 1999.

Simoneit, B. R. T., Rushdi, A. I., bin Abas, M. R., and Didyk, B. M.: Alkyl Amides and Nitriles as Novel Tracers for Biomass Burning, Environ. Sci. Technol., 37, 16-21, 2003.

Sorooshian, A., Murphy, S. M., Hersey, S., Gates, H., Padro, L. T., Nenes, A., Brechtel, F. J., Jonsson, H., Flagan, R. C., and Seinfeld, J. H.: Comprehensive airborne characterization of aerosol from a major bovine source, Atmos. Chem. Phys., 8, 5489-5520, doi:10.5194/acp-8-5489-2008, 2008.

Sun, Y.-L., Zhang, Q., Schwab, J. J., Demerjian, K. L., Chen, W.N., Bae, M.-S., Hung, H.-M., Hogrefe, O., Frank, B., Rattigan, O. V., and Lin, Y.-C.: Characterization of the sources and processes of organic and inorganic aerosols in New York city with a high-resolution time-of-flight aerosol mass apectrometer, Atmos. Chem. Phys., 11, 1581-1602, doi:10.5194/acp-11-15812011, 2011.

Turkiewicz, K., Magliano, K., and Najita, T.: Comparison of Two Winter Air Quality Episodes during the California Regional Particulate Air Quality Study, J. Air Waste Manage., 56, 467-473, 2006.

Ulbrich, I. M., Canagaratna, M. R., Zhang, Q., Worsnop, D. R., and Jimenez, J. L.: Interpretation of organic components from Positive Matrix Factorization of aerosol mass spectrometric data, Atmos. Chem. Phys., 9, 2891-2918, doi:10.5194/acp-9-2891-2009, 2009.

von Glasow, R. and Crutzen, P. J.: Model study of multiphase DMS oxidation with a focus on halogens, Atmos. Chem. Phys., 4, 589608, doi:10.5194/acp-4-589-2004, 2004.

Watson, J. G.: Visibility: Science and Regulation, J. Air Waste Manage., 52, 628-713, 2002.

Watson, J. G. and Chow, J. C.: Comparison and evaluation of in situ and filter carbon measurements at the Fresno Supersite, J. Geophys. Res.-Atmos., 107, 8341, doi:10.1029/2001JD000573, 2002a.

Watson, J. G. and Chow, J. C.: A wintertime PM2.5 episode at the fresno, CA, supersite, Atmos. Environ., 36, 465-475, $2002 \mathrm{~b}$.

Watson, J. G., Chow, J. C., Bowen, J. L., Lowenthal, D. H., Hering, S., Ouchida, P., and Oslund, W.: Air quality measurements from the Fresno Supersite, J. Air Waste Manage., 50, 1321-1334, 2000.

Xu, L., Guo, H., Boyd, C. M., Klein, M., Bougiatioti, A., Cerully, K. M., Hite, J. R., Isaacman-VanWertz, G., Kreisberg, N. M., Knote, C., Olson, K., Koss, A., Goldstein, A. H., Hering, S. V., de Gouw, J., Baumann, K., Lee, S. H., Nenes, A., Weber, R. J., and Ng, N.
L.: Effects of anthropogenic emissions on aerosol formation from isoprene and monoterpenes in the southeastern United States, P. Natl. Acad. Sci. USA, 112, 37-42, 2015.

Young, D. E., Allan, J. D., Williams, P. I., Green, D. C., Flynn, M. J., Harrison, R. M., Yin, J., Gallagher, M. W., and Coe, H.: Investigating the annual behaviour of submicron secondary inorganic and organic aerosols in London, Atmos. Chem. Phys., 15, 63516366, doi:10.5194/acp-15-6351-2015, 2015a.

Young, D. E., Allan, J. D., Williams, P. I., Green, D. C., Harrison, R. M., Yin, J., Flynn, M. J., Gallagher, M. W., and Coe, H.: Investigating a two-component model of solid fuel organic aerosol in London: processes, PM1 contributions, and seasonality, Atmos. Chem. Phys., 15, 2429-2443, doi:10.5194/acp-152429-2015, 2015b.

Yuan, B., Warneke, C., Shao, M., and de Gouw, J. A.: Interpretation of volatile organic compound measurements by proton-transferreaction mass spectrometry over the deepwater horizon oil spill, Int. J. Mass Spectrom., 358, 43-48, 2014.

Zhang, Q., Alfarra, M. R., Worsnop, D. R., Allan, J. D., Coe, H., Canagaratna, M. R., and Jimenez, J. L.: Deconvolution and Quantification of Hydrocarbon-like and Oxygenated Organic Aerosols Based on Aerosol Mass Spectrometry, Environ. Sci. Technol., 39, 4938-4952, 2005a.

Zhang, Q., Canagaratna, M. R., Jayne, J. T., Worsnop, D. R., and Jimenez, J. L.: Time- and size-resolved chemical composition of submicron particles in Pittsburgh: Implications for aerosol sources and processes, J. Geophys. Res.-Atmos., 110, D07S09, doi:10.1029/2004JD004649, 2005b.

Zhang, Q., Jimenez, J. L., Canagaratna, M. R., Allan, J. D., Coe, H., Ulbrich, I., Alfarra, M. R., Takami, A., Middlebrook, A. M., Sun, Y. L., Dzepina, K., Dunlea, E., Docherty, K., DeCarlo, P. F., Salcedo, D., Onasch, T., Jayne, J. T., Miyoshi, T., Shimono, A., Hatakeyama, S., Takegawa, N., Kondo, Y., Schneider, J., Drewnick, F., Borrmann, S., Weimer, S., Demerjian, K., Williams, P., Bower, K., Bahreini, R., Cottrell, L., Griffin, R. J., Rautiainen, J., Sun, J. Y., Zhang, Y. M., and Worsnop, D. R.: Ubiquity and dominance of oxygenated species in organic aerosols in anthropogenically-influenced Northern Hemisphere midlatitudes, Geophys. Res. Lett., 34, L13801, doi:10.1029/2007GL029979, 2007a.

Zhang, Q., Jimenez, J. L., Worsnop, D. R., and Canagaratna, M.: A case study of urban particle acidity and its influence on secondary organic aerosol, Environ. Sci. Technol., 41, 3213-3219, 2007b.

Zhang, Q., Jimenez, J. L., Canagaratna, M. R., Ulbrich, I. M., Ng, N. L., Worsnop, D. R., and Sun, Y.: Understanding atmospheric organic aerosols via factor analysis of aerosol mass spectrometry: a review, Anal. Bioanal. Chem., 401, 3045-3067, 2011.

Zhang, X., Kim, H., Parworth, C. L., Young, D. E., Zhang, Q., Metcalf, A. R., and Cappa, C. D.: Optical Properties of Wintertime Aerosols from Residential Wood Burning in Fresno, CA: Results from DISCOVER-AQ 2013, Environ. Sci. Technol, 50, 16811690, doi:10.1021/acs.est.5b04134, 2016.

Zorn, S. R., Drewnick, F., Schott, M., Hoffmann, T., and Borrmann, S.: Characterization of the South Atlantic marine boundary layer aerosol using an aerodyne aerosol mass spectrometer, Atmos. Chem. Phys., 8, 4711-4728, doi:10.5194/acp-8-47112008, 2008. 